\title{
Kurumsal İtibar ile Finansal Performans Arasındaki İlişkide İnovasyon Kapasitesinin Aracılık Etkisi*
}

Araştırma Makalesi /Research Article

\author{
Elif SİS ATABAY ${ }^{1}$ \\ Kader ŞAHIN ${ }^{2}$
}

ÖZ: Bu araştırmanın amacı kaynak temelli yaklaşım kapsamında Türkiye'de faaliyet gösteren firmaların kurumsal itibarlarının, finansal performansları üzerindeki direkt etkisinin yanı sira, inovasyon kapasitesi üzerinden ortaya çıkabilecek endirekt etkisini ortaya koymaktır. Çalışmada aracılık (mediation) analiz modeli kullanılmıştır. Çalışma 2014-2018 yllları arasinda Brand Finance tarafindan yayınlanan Turkey 100 (Türkiye'nin en Itibarlı Markalar Raporu) listesinde yer alan ve Borsa İstanbul'da işlem gören 35 firmaya ait 175 adet gözlemden oluşmaktadır. Panel EKK "Havuzlanmış Regresyon Modeli" kullanılarak yapılan analiz bulgularl, kurumsal itibarın finansal performans üzerinde anlamll ve pozitif yönlü bir etkisinin olduğunu ve inovasyon kapasitesinin ise bu ilişkide önleyici (supression) bir etkiye sahip olduğunu ortaya koymuştur.

Anahtar Kelimeler: Kurumsal İtibar, Finansal Performans, İnovasyon

JEL Kodu: M10, M19, M21

\section{The Mediating Effect of Innovation Capacity in the Relationship between Corporate Reputation and Financial Performance}

The purpose of this research is to determine the direct effect of corporate reputation on financial performance and as well as the indirect effect that can arise out of innovation capacity of firms operating in Turkey within the framework of resource-based approach. To test these relationships, moderator models were used. The sample of the study consists of 175 observations belonging to 35 companies that are listed in the Turkey 100 list (Turkey's Most Respected Brands Report) published by Brand Finance between 2014-2018 and are listed in BIST. Panel EKK "Pooled Regression Model" was used in the study. The findings of the analysis made using the Panel EKK "Pooled Regression Model" show that corporate reputation has a significant and positive effect on financial performance and innovation capacity has a suppression effect on this relationship.

Keywords: Corporate Reputation, Financial Performance, Innovation

JEL Codes: M10, M19, M21

Geliş Tarihi / Received: 09/02/2021

Kabul Tarihi / Accepted: 12/04/2021

\footnotetext{
*Bu çalışma, "Kurumsal İtibar ile Finansal Performans Arasındaki İlişkide İnovasyon Kapasitesinin Aracı ve Uluslararasılaşma Derecesi ile Aile Üyeliğinin Biçimleyici Etkileri” isimli doktora tezinden üretilmiştir.

${ }^{1}$ Öğr. Gör. Dr., Trabzon Üniversitesi, Turizm ve Otelcilik Meslek Yüksekokulu, satabay@trabzon.edu.tr, orcid.org/0000-0003-3862-6060.

${ }^{2}$ Prof. Dr., Karateniz Teknik Üniversitesi, İktisadi ve İdari Bilimler Fakültesi, kadertan@ktu.edu.tr, orcid.org/0000-0003-2957-1854
} 


\section{Giriș}

Son yıllarda ekonomik dengelerdeki değişim firmaların rekabetçi davranış şekillerinin de değişmesine neden olmuştur. Bu durumun asıl nedeni rekabet avantajı yaratan unsurların maddi unsurlardan daha çok maddi olmayan unsurlara kaymasından kaynaklanmaktadır (Marr, 2005; Porter, 2011). Özellikle stratejik yönetim alanında sürdürülebilir rekabet avantajı elde edebilmenin kurumsal itibar gibi soyut nitelikli (Omar vd., 2009: 177-187) kaynaklarla sağlanabileceği, söz konusu kaynakların ise ikame edilemez, nadir ve değerli (Barney, 1991: 105-108) olması gerektiği vurgusu yer almaktadır. Bu nedenle 2000'li yıllarda kurumsal itibar kavramı birçok akademisyenin dikkatini çekmeyi başarmıştır (Berens ve Van Riel, 2004; Deephouse, 2000; Fombrun ve Shangley, 1990). İyi bir itibar, bir örgütün uzun vadeli başarısı için kritik önem taşımaktadır (Young, 1996). Olumlu kurumsal itibar, firmaların gelecekteki nakit akışlarını güvence altına alarak kurumların kârlılığını artırmakta, yatırımcıları ve müşterileri firmaya çekmekte, yeni pazarlara daha kolay girilmesini sağlamakta böylece pazarda süreklilik sağlayarak rekabet avantajı yakalamayı kolaylaştırmaktadır (İnceöz, 2015: 29-35). Hassas, kolayca değiştirilemeyen ve çeşitli yatırımlardan etkilenebilen kurumsal itibar stratejik bir kaynak niteliği taşımasının yanı sıra (Fombrun ve Shanley, 1990: 235) firmaların uzun dönemli rekabet avantajı elde etmelerine katkıda bulunan stratejik bir başarı faktörü olarak değerlendirilmektedir (Vitezic, 2011: 87). Güçlü kurumsal itibar firmaların sermaye maliyetlerini düşürmekte (Beatty ve Ritter, 1986) ve sermaye piyasalarına girişlerini kolaylaştırmakta (Schwalbach, 2000: 285) böylece firmanın kârlılığı da olumlu itibarıyla birlikte büyümektedir (Schwaiger, 2004: 50). Bu açıdan stratejik yönetim literatüründe kurumsal itibarla finansal performans arasındaki ilişkinin boyutlarının/yönünün ele alınarak açıklığa kavuşturulması dikkat çekici bir konu haline gelmiştir.

Kurumsal itibarla finansal performans arasındaki ilişki, genellikle öncül çalışmalarda doğrudan bir ilişki olarak ele alınmıştır (Carmeli ve Tishler, 2005; Boyd vd., 2010; Roberts ve Dowling, 2002) ancak aralarındaki ilişkinin yönü ve büyüklügü konusunda farklı sonuçlar elde edilmiştir (Rose ve Thomsen, 2004). İnovasyon faaliyetleri sonucunda ortaya çıkan her yeni ürün/hizmet, pazara girdiğinde yenilik yükümlülügü ile karşı karşıya kalmaktadır. İtibarın kritik boyutlarından biri olan inovasyonun, bir firmanın avantaj ve müşteri sadakati elde etmesini sağlayan ayırt edici bir faktör olarak ortaya çıktığı düşünüldüğünde (Hull ve Rothenberg, 2008), firma itibarı ne kadar yüksekse müşteri sadakati ile markanın yenilikçi ürünlerinin kabul edilme oranının da aynı ölçüde yüksek (Li vd., 2016) olacağ 1 öne sürülmektedir. Bu noktada firmaların inovasyon faaliyetleriyle, rakiplerine göre rekabetçi konumunu güçlendirerek sürdürülebilir bir finansal performans elde edebilecekleri düşünülmektedir. Böylelikle inovasyon faaliyetleri firmaya, pazardaki diğer kuruluşlardan sürekli olarak daha iyi performans göstermesi için gerekli yetenekleri ve ayırt edici yetkinlikleri sağlamak konusunda önemli bir araç olmaktadır (Damanpour vd., 2009: 656). 
İnovasyon faaliyetleri finansal performans üzerinde etkili olabilecek önemli bir stratejik karar olarak gündeme gelmektedir. Ancak bu çalışmada hem kurumsal itibarın finansal performans üzerindeki etkileri araştırma konusu yapılırken hem de firmaların finansal çıktılarına katkı sağlayabilecek veya zarar verebilecek olan inovasyon faaliyetlerinin ilişkide nasıl bir rol oynayacağı sorusuna cevap aranmaktadır. Araştırmanın literatürdeki öncül çalışmaların ötesinde sağlayacağı temel katkısı, söz konusu ilişkiye aracılık edecek inovasyon gibi stratejik kararların etkisini ortaya çıkarılmak için inovasyonun modele dâhil edilmesi sonucunda öngörülen ilişkinin kaynak temelli yaklaşım kapsamında daha geniş bir bakış açısından ele alınmasıdır. Bu çalışmanın, kurumsal itibar ve finansal performans arasındaki ilişkiye odaklanarak ilgili yazına katkı sağlayacağı düşünülmektedir. 2014-2018 yılları arasında Brand Finance tarafından yayınlanan Turkey 100 (Türkiye'nin en İtibarlı Markalar Raporu) listesinde yer alan ve Borsa İstanbul'da işlem gören 35 firma üzerinde gerçekleştirilen araştırma, kaynak temelli yaklaşım kapsamında kurumsal itibar ile finansal performans arasındaki ilişkide inovasyon kapasitesinin aracılık etkisini ele almaktadır. Çalışmada literatür kapsamında kavramsal bir çerçeve oluşturulmuş ve araştırma modeli tanımlanarak hipotezler geliştirilmektedir. Ardından, araştırmanın bulguları sunulmakta, çalışma sonuç bölümü ile sonlanmaktadır.

\section{Kavramsal Çerçeve ve Araştırma Modeli}

Günümüzde değişen ve gelişen piyasa şartlarının sonucu olarak özellikle 2000'li yıllarda kurumsal itibar kavramı birçok akademisyenin dikkatini çekmiştir (Berens ve Van Riel, 2004; Deephouse, 2000; Fombrun ve Shangley, 1990). Türkçede saygınlık (http://www.tdk.gov.tr) kelimesi ile açıklanan itibar kavramı, insanların bir kişi veya bir şey hakkındaki genel düşünce, bir kişi ya da bir şeyin geçmiş davranışlarına dayalı olarak ne kadar takdir edildiğini ifade etmektedir (http://dictionary.cambridge.org). İtibar, bir firmanın zaman içinde paydaşları nezdinde oluşan yansıması olarak tanımlanmaktadır (Kadıbeşegil, 2006: 37). Kurumsal itibar kavramı ise bir firmanın geçmişinden hareketle bu firmaya atfedilen özelliklerin bütünüdür (Weigelt ve Camerer, 1988: 443). Hall (1992: 138), bir firmanın itibarının bireylerin sahip olduğu bilgi ve duygulardan oluştuğunu ifade etmektedir. İtibar, çok sayıda yazar tarafından değerli bir maddi olmayan varlık olarak ele alınmıştır (Barney, 1991; Fombrun, 1996). Kurumsal itibar kavramına yönelik birçok tanım yapılmış olmasına rağmen tanımların ortak noktası kurumsal itibarın dinamik bir kavram olduğudur (Gray ve Balmer, 1998; Rindova, 1997; Fombrun, 1996). Kurumsal itibar firmaların firsatları değerlendirmeleri ve tehditleri azaltmalarına olanak sağlayan önemli bir varlık niteliğindedir (Argenti ve Druckenmiller, 2004). Bu noktada özellikle stratejik yönetim alanında kullanılan kaynak temelli yaklaşım, sürdürülebilir rekabet avantajının itibar ve marka gibi soyut yeteneklerle yaratıldığını ifade etmektedir (Omar vd., 2009: 177-178). Firmanın iç kaynaklarına odaklanan kaynak temelli yaklaşımda kurumsal itibar soyut nitelikli firma iç kaynağı olarak kabul edilmekte 
ve kaynaklar, stratejilerin oluşturulması yoluyla firmaların ekonomik çıktılar elde etmelerini sağlayan varlıklar olarak görülmektedir (Barney, 1991).

Kaynak temelli yaklaşım, itibarı firmanın bir kaynağı olarak ele almaktadır. Güçlü bir itibarın sonucuna odaklanan kaynak temelli yaklaşım, kurumsal itibarın genellikle eylem sonrası bir aşamada uygulandığını vurgulamaktadır (Walker, 2010). Kaynak temelli yaklaşım kapsamında itibar, değerli ve nadir bulunan soyut bir kaynaktır; çünkü itibarı taklit etmek zordur ve nedensel olarak oldukça belirsizdir. Belirsizlik durumlarında firma itibarının ürün kalitesine yönelik sunduğu sinyaller firmaya yönelik belirsizliklerin azalmasına yardım etmektedir (Rindova vd., 2005) ve böylece itibar daha yüksek finansal performans1 beraberinde getirmektedir (Roberts ve Dowling, 2002). Kaynak temelli yaklaşıma göre firmalar için kurumsal itibarın en önemli çıktısı finansal performans çıktısıdır. Finansal performans çıktısı diğer teori ve yaklaşımlarda ise göze çarpmamaktadır (Yener ve Ergün, 2014: 19-20).

Kurumsal itibar günümüzde firmaları rakiplerinden daha güçlü kılan ve onları rakiplerinden ayıran bir ayırıcı görevi görmektedir . Kurumsal itibar, müşterileri yeniden satın almaya ve ürünler için isteyerek daha yüksek fiyat ödemeye çeken maddi olmayan bir varlık olarak ortaya çıkmaktadır (Eberl ve Schwaiger, 2005; Roberts ve Dowling, 2002).

Bazı firmalarda, firma itibarı doğrudan ürün inovasyonu ile ilişkilidir, çünkü bu firmalar öncelikle inovasyona ve ürün geliştirmeye odaklanmıştır (Henard ve Dacin, 2010). Firma itibarının kendisi, firmanın yenilikçi davranışını etkilemektedir (Li vd., 2016). Bir firmanın yüksek itibarı, müşterilerin ürün kalitesine yönelik beklentilerini de artırmaktadır (Rhee, 2009). Ayrıca Stuart (2000), bir firmanın itibarının, yüksek kaliteli insan kaynaklarını işe alma ve büyük oranlarda yenilikçi projeleri başlatmak için gerekli olan fonları ve piyasa pozisyonlarını elde etme kabiliyetini etkilediğini ileri sürmektedir. Bu nedenle, yüksek bir firma itibarına sahip olmanın, daha yenilikçi davranış sergilemek için teşvikler sağladığı iddia edilebilir. Ayrıca firmalar, rakiplerinden farklılaşmak ve rekabet avantajı elde etmek için ürün yenilikleri yapmaktadırlar (Galende ve De La Fuente, 2003).

İnovasyonla ilgili literatür, araştırma ve geliştirmenin (Ar-Ge) bilimsel bilgi stokunun oluşmasına yol açtı̆ğna işaret etmektedir (Griliches, 1979). Bir firma bu bilgiyi, yenilikleri ve yetkinlikleri geliştirmek; performansını iyileştirmek için farklı şekillerde kullanabilir. Örneğin, daha verimli süreçler geliştirerek, mallarının üretimiyle ilgili maliyetleri azaltabilir. Yeni ürünler sunarak veya mevcut ürünlerinin kalitesini artırarak pazar payını ve satışlarını artırabilir (Mansfield, 1968). İnovasyon ve iş büyümesi arasındaki pozitif ilişki birçok farklı koşul altında test edilmiş ve kanıtlanmıştır ( $\mathrm{Li} \mathrm{vd.,} \mathrm{2016).} \mathrm{İnovasyon,} \mathrm{uzun} \mathrm{vadeli}$ ticari büyümeyi sürdürmek için önemli bir araç niteliğindedir. Bu noktada kaynak temelli yaklaşım kapsamında hem kurumsal itibar hem de inovasyon faaliyetleri firmaların finansal performanslarında bir artışa neden olabilecek önemli bir 
kaynak olarak değerlendirilmektedir. Yazında firmaların sahip oldukları kurumsal itibarın inovasyon kapasitesini etkilediği ve yüksek itibarlı firmaların inovasyon faaliyetlerinin de yüksek olabileceğine yönelik sonuçlar yer almaktadır (örneğin, Steenvoorden, 2017; Friar, 1995; Mansfield, 1961). Bu bağlamda kurumsal itibar ve finansal performans arasındaki ilişkide inovasyon kapasitesinin aracı (mediator) bir etkisinin olup olmayacağını düşünülmesi gereken bir durum olmuştur.

Kaynak temelli yaklaşım kapsamında, kurumsal itibar ve finansal performans arasındaki ilişki ve bu ilişkide inovasyon kapasitesinin rolünü belirlemek için oluşturulan "aracılık" modeli (Baron ve Kenny, 1986; Mathieu ve Taylor, 2006: 1032) Şekil 1'de görülmektedir. "Aracı" temel olarak bir öncül değişkeni bir kriter değişkene bağlayan bir tür bağlantı mekanizması olarak tanımlanmaktadır (Mathieu ve Taylor, 2006: 1038-1039). Model, bağımsız değişken (kurumsal itibar) ile bağımlı değişken (finansal performans) arasındaki ilişkinin "neden" veya "nasıl" ortaya çıktığını ortaya koyma şeklinde tanımlanmaktadır (Judd ve Kenny, 1981: 206; Baron ve Kenny, 1986: 1176). Söz konusu modelin testinde, kurumsal itibar ve finansal performans arasındaki ilişkinin ne kadarlık bir kısmının inovasyon üzerinden açıklanabileceği ortaya konulacaktır. Modelde yer alan bağımsız değişken ve bağımlı değişken arasındaki toplam etkinin (c) aracı değişken tarafından açıklanan bu kısmı (a.b), endirekt etki olarak isimlendirilmekte ve toplam etki ile direkt etki (c') arasındaki farkı ifade etmektedir (a.b=c-c') (Hayes, 2009: 409).

Şekil 1: Kurumsal İtibar ile Finansal Performans Arasındaki İlişkide İnovasyonun Aracılık Etkisi

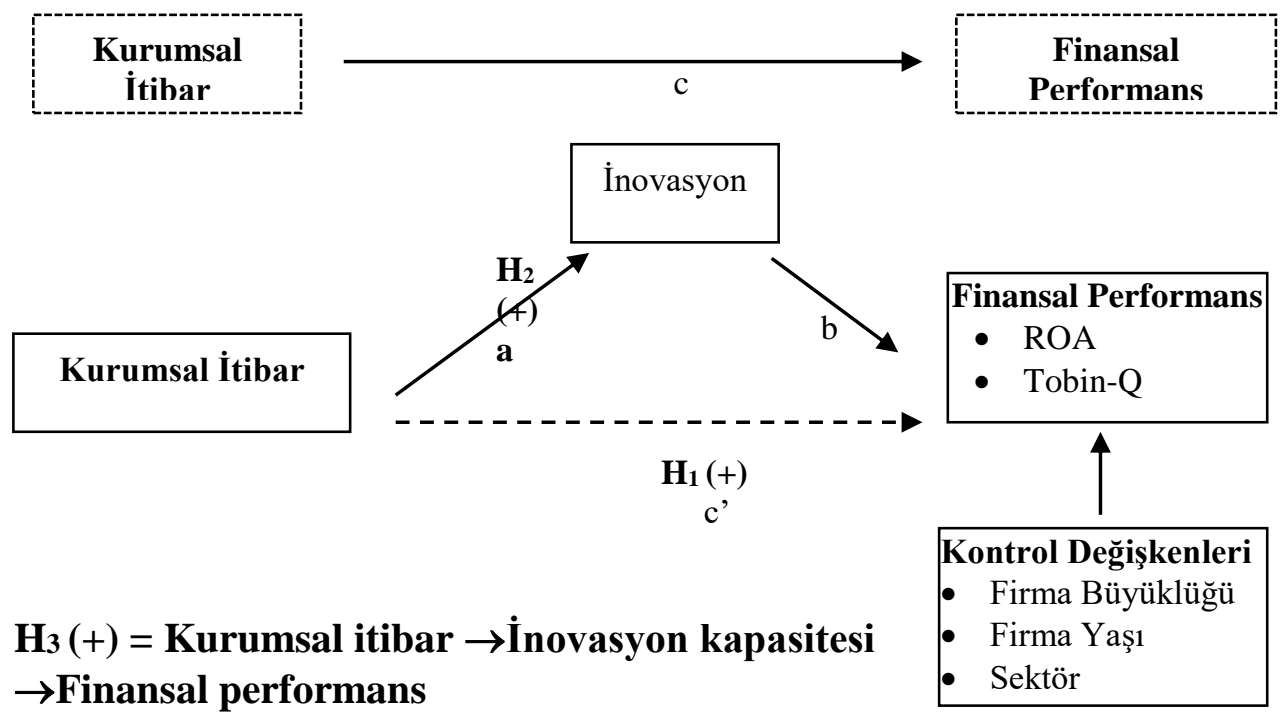

Ayrıca, aracılık ilişkisinin bazı durumlarda alternatif biçimlerde ortaya çıkabileceğini öne süren MacKinnon vd., (2000), "bağımlı değişken ile bağımsız değişken arasındaki direkt (Şekil 1, Yol c') ve endirekt (Şekil 1, Yol a.b) ilişkinin 
işaretlerinin farklı olması ve direkt etkinin katsayısının (Şekil 1, Yol c') toplam etkinin katsayısından (Yol c) daha büyük olması durumunda istikrarsız aracılık (inconstistent mediation) ya da önleyici (suppression) etkinin" ortaya çıkacağını öne sürmüşlerdir.

\section{Literatür Taraması ve Hipotezler}

\subsection{Kurumsal İtibarın Finansal Performans Üzerindeki Etkisi}

Son zamanlarda, strateji araştırmacıları dikkatlerini rekabet avantajının kaynağı olarak firma içindeki kaynakların rolüne odaklanmış ve 50 yılda birçok yönetim akademisyeni bu konunun geliştirilmesine katkıda bulunmuştur (Penrose, 1959; Barney, 1991). Kurumsal itibarın önemi ve yönetilmesi, henüz firmalar tarafindan tam olarak bilinmese de önemli bir meseledir çünkü kurumsal itibarın firmalar üzerinde uzun vadeli etkileri olduğu ileri sürülmektedir (Fang, 2005). İtibar bir alg1 bütünüdür ve bir kere yaratılırsa paydaşlar ile toplumun zihnindeki algıyı değiştirmek çok zor olmaktadır (De Castro vd., 2006: 361).

Kaynak temelli yaklaşım, kurumsal itibarı yeri doldurulamaz, sürdürülebilir rekabet avantajına yol açabilecek bir kaynak olarak görmekte ve bu etkilerin nasıl sonuçlandığını incelemektedir (Flanagan ve Q'Shaughness, 2005). Kaynak temelli yaklaşım perspektifinde, özellikle stratejik yönetim alanında sürdürülebilir rekabet avantaj1 elde edebilmenin itibar gibi soyut nitelikli (Omar vd., 2009: 177-187) kaynaklarla sağlanabileceği, kaynakların ise ikame edilemez, nadir ve değerli (Barney, 1991: 105-108) olması gerektiği vurgusu yer almaktadır.

Kurumsal itibar firmalara sağladığı birçok avantajı nedeniyle literatürde birçok araştırmacı tarafından ele alınmış ve kurumsal itibar ve firma performansı arasında olumlu ilişkiler kurulmuştur (Fombrun ve Shanley, 1990). Kurumsal itibar ve finansal performans arasındaki ilişki inceleyen araştırmacılar, daha yüksek kurumsal itibarın daha yüksek firma performansına neden olduğu ve itibarın finansal performans ile pozitif olarak ilişkili olduğu sonucuna ulaşmışlardır (Boyd vd., 2010; Rindova vd., 2010; Roberts ve Dowling, 2002). Fombrun ve Shanley (1990) sağlam kurumsal itibarın, firma büyümesini teşvik edebilecek yatırımların beklenen getirisi ile olumlu bir ilişki içerisinde olduğunu savunmaktadır. Petkova vd., (2014: 422), bir firmanın itibarının gelecekteki performansını artırabileceğini belirtmektedir. Ayrıca Roberts ve Dowling (2002), 1994-1998 yılları arasında Fortune'un raporlarını kullanarak kurumsal itibar ve finansal performans arasındaki ilişkiyi incelemiş ve görece iyi itibara sahip firmaların avantajlarını daha iyi sürdürdüklerini bulmuşlardır. İlişkiye yönelik Türkiye'de yapılan çalışmalara baktığımızda, Yeşil ve Purtaş (2017), tekstil sektöründe yaptıkları alan çalışmasında kurumsal itibarın firma performansını pozitif yönde etkilediği sonucuna varmışlardır. Saylı vd., (2009: 171), Türkiye'nin ilk 500 büyük işletmesi için yaptıkları çalışmada finansal performans göstergeleriyle kurumsal itibar arasında anlamlı ilişki tespit edemezken, müşteri 
memnuniyeti ve kalite arasında kurumsal itibarla pozitif yönde anlamlı ilişkiler tespit etmişlerdir.

Kurumsal itibarın hem rekabet avantajı hem de sermaye yaratmadaki rolü kaynak temelli yaklaşım tarafından teorik bir temele oturtulmaktadır (De Castro vd., 2004: 580). Ancak literatürde, kurumsal itibarla finansal performans arasındaki ilişkilerin varlığı farklı nedenlere bağlanmaktadır. İlk olarak, itibar firmaların çeşitli yönlerini kapsamaktadır; ancak önceki çalışmalar kurumsal itibarın önemli boyutlarını araştırmış olsalar da itibarın çok yönlülüğünü inceleyerek, itibar ve performans arasındaki bağlantının daha büyük bir resmini anlama noktasını desteklememektedir (Lee ve Roh, 2012: 650). Bu noktada çalışmanın teorik çerçevesini sunan kaynak temelli yaklaşım önemli bir rol üstlenmektedir. İkinci olarak, firma itibarının performans üzerinde çok boyutlu bir etkisi bulunmaktadır. Özellikle kaynak temelli yaklaşım kurumsal itibarın nasıl sürdürüldüğü ve ne tür çıktılar sağladığı noktasında önemli bir teorik bakış açısı sunmaktadır. Literatür ve kavramsal açıklamalar 1şığında firmaların sahip olduğu kurumsal itibar ile finansal performansları ilişkisine yönelik aşağıdaki hipotez geliştirmiştir.

H1: Kurumsal itibar finansal performans üzerinde pozitif yönlü bir etkiye sahiptir.

\subsection{Kurumsal İtibarın Finansal Performans Üzerindeki Etkisi}

Sanayi üretiminin yaygınlaşmasıyla birlikte yenilik çalışmalarına dayalı rekabetin önemi de giderek artmıştır (Öğ̈̈t vd., 2007). Artan rekabetle birlikte firmalar rekabet avantajı elde etmek için girişimcilik yeteneklerini değerlendirmeye ve inovasyon stratejilerini uygulamaya başlamışlardır (Hult vd., 2003). Piyasadaki varlığını devam ettirmek isteyen firmalar, sürdürülebilir rekabet üstünlüğü elde etmek için göreceli olarak daha çok değer yaratmalıdır. İtibarın kritik boyutlarından biri olan inovasyon, bir firmanın avantaj ve müşteri sadakati elde etmesini sağlayan ayırt edici bir faktör olarak ortaya çıkmaktadır (Hull ve Rothenberg, 2008). İnovasyon faaliyetleri sonucunda ortaya çıkan her yeni ürün / hizmet, pazara girdiğinde yenilik yükümlülügü ile karşı karşıya kalmaktadır. Bu nedenle firma itibarı ne kadar yüksekse müşteri sadakati de yüksek olmakta ve markanın yenilikçi ürünlerini kabul etmek kolaylaşmaktadır (Li vd., 2016). Kim ve Mauborgne (2005), süreç ve stratejide yenilikçi düşüncenin rakipler karşısında sürdürülebilir bir avantajın yolunu açabileceğini iddia etmişlerdir. Roberts ve Dowling (2002: 1091), Iyi bir itibarın gelişmesi önemli ölçüde zaman alır ve bir firmanın zaman içinde istikrarl ve tutarl yatırımlar yapmasına bağlıdır. vurgusunu yapmışlardır. Araştırmacılar ayrıca, kurumsal itibarın, üstün çalışanları ve sermayeyi uygun koşullarda çekmeye ve genel olarak bir dizi paydaş ilişkisinde pazarlık avantajları sağlamaya yardımcı olduğunu da açığa çıkarmışlardır (Boyd vd., 2010; Rose ve Thomsen, 2004; Roberts ve Dowling, 2002).

Ayrıca kaynak temelli yaklaşım açısından, yenilik sadece pazar firsatları için dış ortamı taramaktan değil; kurumun temel yetkinliklerini oluşturmak ve geliştirmek 
için içeriye bakmaktan gelmektedir (Del Canto ve Gonzalez, 1999: 894). İnovasyon teşvikleri, firmaya kaynak temininde de bulunabilmesidir. Bu nedenle yenilik, heterojen ve firmalar arasında hareketsiz olan belirli kaynaklara bağlıdır ve inovasyon davranışı, firma içi kaynakların bir işlevi olarak tanımlanmaktadır (Del Canto ve Gonzalez, 1999: 894). Del Canto ve Gonzalez (1999), maddi olmayan kaynakların inovasyon faaliyetlerinin yürütülmesi ile olumlu şekilde ilişkili olduğunu bulmuştur. İtibarı yüksek firmaların inovasyon faaliyetlerini yürütme olasılığının daha yüksek ve dolayısıyla daha yenilikçi davranışlara sahip olduklarını göstermektedir. Firmanın kurumsal itibarı firmanın yenilikçi davranışını etkilemektedir (Steenvoorden, 2017). Bir firmanın itibarı yüksek olduğunda, paydaşlarının onlardan beklentileri de yüksek olmaktadır (Petkova vd., 2014: 425). Bu beklentileri karşılamak için sadece finansal performansı sürdürmek yeterli olmamaktadır (Mishina vd., 2010).

Kurumsal itibara sahip firmalar finansal performanslarını artırmak için performans sürdürme yolunu izlemeyi bırakıp bunun yerine yeni ve daha riskli firsatlar aramaları gerekmektedir (Petkova vd., 2014: 425). Yüksek itibarlı firmaların böylesine cesur ve riskli stratejik hareketlerine örnek olarak, Google'ın sürücüsüz otomobilleri geliştirmesi ve Apple'ın mobil ve eğlence cihazlarının piyasaya sürülmeleri verilebilir (Petkova vd., 2014: 425). Bunlar yenilikçi davranış örnekleri olarak sayılmaktadır. Ayrıca Mansfield (1961) itibarı yüksek olan firmaların, müşterilerin beklentilerini karşılamak için yüksek düzeyde yenilikçi davranış sergileyeceklerini söylemektedir. Kaynak temelli yaklaşımdan yola çıkan araştırmalar, diğer firmaların sahip olmadığı bilgiye, yetkinliklere ve üstün/yeni ürünlere sahip olan inovatif firmaların yüksek performansa ulaşacağını savunmaktadır (Friar, 1995). MacAlister (2016), inovasyonun bir sonucu olarak beklenen yeni yatırım getirisinin mevcut veya inovasyon dışı yatırım getirisinden daha yüksek olduğunu savunmuştur. Bu nedenle, yüksek itibara sahip firmaların, kendi istek düzeylerine ulaşmak için yüksek düzeyde yenilikçi davranış sergileyecekleri söylenebilir.

Kurumsal itibar ile inovasyon konusunda Türkiye'de yapılan çalışmalara bakıldığında, genellikle Türkiye'nin inovasyon açısından gelişmiş, hızlı büyüyen ve gelişmekte olan ülkeler arasındaki yerine (Özbek ve Atik, 2014; Ersöz 2009) yönelik çalışmalar yer almaktadır. Firmaların kurumsal itibarlarının inovasyon faaliyetleri üzerinde nasıl bir etki yarattığına yönelik bir çalışmaya ise yazar tarafından rastlanılmamıștır. Ancak, Bala ve Utluc (2020), tarafindan yapılan çalışmada inovasyon ile kurumsal itibarla birçok açıdan aynı anlamda kullanılan kurumsal imaj kavramı arasında pozitif yönlü yüksek bir ilişki olduğu tespit edilmiştir. Yücel ve Toprak (2019), tarafından sosyal inovasyonun firma imajına etkisine yönelik gerçekleştirilen çalışmada, inovasyonun firmanın marka imajını pozitif yönde etkilediği sonucu elde edilmiştir. Harmancıoğlu (2012), kaynak temelli yaklaşım varsayımları eşliğinde yeni ürün inovasyonu ile yeni ürün performansı arasında pozitif bir ilişki olduğunu ön gördüğü çalışmada, inovasyon ve firma ürün performans arasında pozitif yönde ilişki tespit etmiştir. 
Maddi olmayan bir varlık olan kurumsal itibar, inovasyon için bir itici güç olarak kabul edilmektedir. Yukarıda verilen literatür ve kavramsal açıklamalar 1şığında, kaynak temelli yaklaşıma göre firmaların sahip olduğu kurumsal itibarın firmaların inovasyon faaliyetleri üzerinde etkili olması beklenmektedir. $\mathrm{Bu}$ kavramsal açıklamalar ışı̆̆ında aşağıdaki hipotez geliştirmiştir

H2: Kurumsal itibar, inovasyon kapasitesi üzerinde pozitif bir etkiye sahiptir.

\section{3. İnovasyon Kapasitesinin, Kurumsal İtibar ve Finansal Performans Arasındaki İlişkide Aracı (Mediator) Etkisi}

İnovasyon, firmalar açısından değer yaratan bir unsur olarak bu noktada dikkat çekicidir. İnovasyon faaliyetleri firmalara sürdürülebilir rekabet avantajı elde etme noktasında karşılaştıkları sorunların üstesinden gelmeleri için stratejik bir yönelim sağlamaktadır (Kuratko vd., 2005; Hitt vd., 2001). Porter'a (1990) göre firmalar inovasyon çalışmalarına rekabet avantajı sağladığı için hem yeni teknolojileri hem de yeni iş yapış şekillerini kapsayan daha geniş bir perspektiften baktıkları görüşünü savunmaktadır. Kaynak temelli yaklaşımın temel argümanları inovasyonu değerli bir kaynak olarak değerlendirmektedir. Firmaların temel amaçları iç kaynaklarına odaklanarak piyasada rekabet üstünlüğü elde etmenin yollarını sağlamaktır.

İnovasyon çalışmaları ve firmanın piyasa değeri arasındaki ilişkiyi inceleyen BenZion (1984) gibi bazı araştırmalar, inovasyonun, muhasebe kârları ve uzun vadeli hissedar getirileri arasında olumlu etkisi olduğunu belirtmektedir. Dowling (2000), iyi bir kurumsal itibara sahip olmanın yeni ürünlerin tanıtımını destekleyeceğini ileri sürmektedir. Yani, yüksek itibar firmanın daha yenilikçi davranış sergilemesini teşvik etmektedir. Çünkü yeni ürün tanıtımları gibi bu yenilikçi davranışın sonuçları muhtemelen itibarları tarafından desteklenecek ve sonuç olarak başarı şansı daha yüksek olacaktır. Bazı firmalarda, firma itibarı doğrudan ürün inovasyonu ile ilişkilidir, çünkü bahsi geçen firmalar öncelikle inovasyona ve ürün geliştirmeye odaklanmıştır (Henard ve Dacin, 2010). Kısacası, ürün yeniliği konusunda yüksek itibara sahip firmaların mantıksal olarak yüksek düzeyde yenilikçi davranışa sahip olacağı ileri sürülebilir. Kurumsal itibar gibi somut olmayan ticari kaynaklar, genellikle Ar-Ge'nin bir sonucu olarak ortaya çıkan yeniliklerden uygun şekilde yararlanmak için gerekli tamamlayıcı kaynaklar olma potansiyeline sahiptir (Steenvoorden, 2017). Stuart (2000), firma itibarının, yüksek kaliteli insan kaynaklarını işe alma ve büyük oranlarda yenilikçi projeleri başlatmak için gerekli olan fonları ve piyasa pozisyonlarını elde etme kabiliyetini etkilediğini ileri sürmektedir. Bu durumun, yüksek bir firma itibarına sahip olmanın, daha yenilikçi davranış sergilemek için teşvikler sağladığı iddia edilmektedir. Galende ve De La Fuente (2003) araştırmalarında bir firmanın yenilikçi davranışını hangi iç faktörlerin belirlediğini incelemiş ve bilgi, firma itibarı, imaj, insan kaynakları gibi birçok ticari kaynağa sahip olmanın inovasyon çalışmalarını etkilediğini göstermişlerdir. 
Kurumsal itibarla inovasyon kapasitesi arasındaki ilişki birçok araştırmacı tarafından ele alınmış ve yüksek itibarın inovasyon kapasitesini arttırdığ 1 sonucuna ulaşılmıştır (Stuart, 2000; Galende ve De La Fuente, 2003). Ayrıca yüksek inovasyon kapasitesi firmaların rekabetçi konumunu güçlendirerek, piyasada etkin ve önemli roller oynamalarında büyük katkı sağlamaktadır (Güleş ve Bülbül, 2004: 155). Bu yüzden de firmaların başarılarında yaratıcı ve yenilikçi olabilmeleri büyük önem taşımaktadır. Firmada yenilik faaliyetleri durduğunda ekonomik büyümenin yavaşladığı ve firmayı giderek atıl duruma getirdiği düşünülmektedir (Metcalfe, 1998). Firmaların inovasyondan fayda sağlayabileceğine (Teece, 1986) ve inovasyonun firma performansı üzerinde olumlu bir etkiye sahip olduğuna yönelik birçok çalışma bulunmaktadır (Gopalakrishnan, 2000). Örneğin Yeşil vd., (2010: 84) göre günümüzde artık inovasyonun olmadığı yerde büyümeden ve rekabetçilikten söz edilememektedir. $\mathrm{Bu}$ nedenle yenilik, firmalar, bölgeler ve hatta ülkeler arasında performans ve rekabet farklılıklarının yaratılmasında önemli bir rol oynamaktadır. Benzer şekilde Clark ve Griliches $(1984 ; 393)$ örgüt düzeyinde yaptıkları çalışmada finansal performans ve inovasyon arasında pozitif yönlü sonuçlar elde etmişlerdir. Türkiye'de yapılan çalışmalar incelendiğinde uluslararası literatürle benzerlikler olduğu görülmektedir. Örneğin Gunday (vd., 2020), Türkiye imalat sanayinde yer alan 184 firma ile gerçekleştirdikleri çalışmada inovasyon faaliyetlerinin firmaların finansal performans çıktıları üzerinde olumlu etkisi olduğu sonucunu bulmuşlardır. Yavuz (2010), firmaların inovasyon ve performans ilişkilerine yönelik yaptığı çalışmada, firmaların uygun şartları sağlayarak inovasyona yönelmeleri sonucunda firma finansal performansı arasında anlamlı bir ilişki olduğu sonucuna ulaşmıştır. Harmancıoğlu (2012), kaynak temelli yaklaşım varsayımları eşliğinde yeni ürün inovasyonu ile yeni ürün performansı arasında pozitif bir ilişsi olduğunu ön gördüğü çalışmada, inovasyon ve firma ürün performans arasında pozitif yönde ilişki tespit etmiştir. Aslan ve Aygün (2019), BİST'te imalat sanayisinde yer alan 182 firma üzerinde gerçekleştirilen araştırma sonucunda, imalat sanayisinde yer alan firmalarda inovasyon faaliyetlerinin, finansal performansı üzerinde anlamlı pozitif bir etkisi olduğunu sonucunu elde etmişlerdir.

Kurumsal itibarda olduğu gibi inovasyon faaliyetlerine yapılan yatırımın da uzun vadeli ekonomik performans üzerindeki iyileştirici etkileri uzun süredir tartışılmaktadır (Griliches, 1979). Moore'un (1999) etkili bir pazar konumlandırma meselesi olarak inovasyon faaliyetlerine bakış açısı, finansal fayda konusunda itibar yönetiminin önemli bir örneğidir. İnovasyon, firmaların hem verimliliğini hem de kârlılığını artırma potansiyeli taşımasından dolayı ticari açıdan büyük öneme sahiptir.

Yukarıda verilen açıklamalar ve literatür kapsamında, kurumsal itibar firmaların inovasyon faaliyetlerini etkileyen önemli bir etken olarak ele alınırken; finansal performans inovasyon faaliyetlerinin bir sonucu olarak değerlendirilmektedir. Bu kapsamda inovasyon kapasitesinin kurumsal itibar ile finansal performans 
arasındaki ilişkide aracılık edeceği düşünülebilir. Daha önce değinilen literatür kapsamında kurumsal itibarın, firmanın inovasyon kapasitesi üzerinde de etkili olacağı öngörülmektedir $\left(\mathrm{H}_{2}\right)$. İnovasyonun firmanın finansal performans1 üzerindeki pozitif etkisi göz önüne alınacak olursa, kurumsal itibarının finansal performans üzerindeki etkisinin belirli bir kısmının, firmanın inovasyon kapasitesi üzerinde ortaya çıkabileceği düşünülebilir. Bu varsayımlar 1şı̆̆ında, inovasyon kapasitesinin, kurumsal itibar ve finansal performans arasındaki ilişkide bir aracılık etkisinin olacağı öngörülmüş ve aşağıdaki hipotez geliştirilmiştir.

H3: İnovasyon kapasitesinin, kurumsal itibar ve finansal performans arasındaki ilişskide aracı (Mediator) değişken olarak rol oynar.

\section{Araştırma Yöntemi}

\section{1. Örneklem}

Çalışma örgüt düzeyinde yürütülmüştür. Çalışmanın amacı ve değişkenlerin ölçülmesi konusundaki kısıtlar dikkate alınarak belirlenen evrenini, 2014-2018 yıllarında Brand Finance Turkey 100 (Türkiye'nin En Değerli Markalarının Yıllık Raporu) listesinde yer alan ve BİST'te koteli olan firmalar oluşturmaktadır. Çalışmanın örnek kütlesinin belirlenirken genel olarak imalat ve diğer sektörlerden farklı yapıları nedeniyle finans kurumları ve bankalar örnekleme dâhil edilememiştir. Örnekleme dâhil edilen firmaların $(n=35)$ faaliyette bulundukları sektörlere dağılımları Tablo 1'de özetlenmektedir. Tablo 1'e göre örneklem kapsamında incelenen firmaların ağırlıklı olarak imalat sektöründe yer aldıkları ve oransal olarak örneklemin $\% 52,8$ 'ini oluşturdukları görülmektedir. İşletmelerin faaliyet gösterdikleri 5 sektör ise örneklemim \%48,2'lik kısmını oluşturmaktadır.

Tablo 1: Örnekleme Dâhil Edilen Firmaların Sektörlere Göre Frekans Dağılımları

\begin{tabular}{|l|c|c|}
\hline \multicolumn{1}{|c|}{ Sektör } & Frekans & Yüzde \\
\hline İmalat Sanayi & 19 & 54,2 \\
\hline Ulaştırma, Haberleşme ve Depolama & 5 & 14,3 \\
\hline Toptan ve Perakende Ticaret & 7 & 20,0 \\
\hline Teknoloji & 2 & 5,7 \\
\hline Mali Kuruluşlar/Holdingler & 2 & 5,7 \\
\hline İnşaat ve Bayındırlık & 1 & 2,8 \\
\hline Toplam & $\mathbf{3 5}$ & $\mathbf{1 0 0}$ \\
\hline
\end{tabular}

\subsection{Değişkenler ve Ölçümleme}

Çalışmada bir bağımlı değişken (finansal performans), bir bağımsız değişken (kurumsal itibar) ve bir de aracı değişken (inovasyon kapasitesi) kullanılmıştır. Ayrıca finansal performansı etkileyeceği düşünülen üç kontrol değişkeni (sektör, firma yaşı, firma büyüklüğü) ele alınmıştır.

Bağımlı değişken: Hitt vd., (1997) yaptıkları çalışmada finansal performans göstergelerinden ROE'nin (özsermaye kârlılığı) firmanın sermaye yapısına çok duyarlı olduğunu ayrıca, ROS ve ROA'nın ise aralarında yüksek korelasyon 
olması nedeniyle çoğunlukla benzer sonuçlar üreteceklerini öne sürerek bağımlı değişken olarak sadece ROA'yı kullanmışlardır. Finansal performansı ölçümlemek üzere, öncül çalışmalar da (örneğin Hitt vd.,1997; Okan vd., 2014) referans alınarak firmanın yaygın olarak kullanılan kârlılık oranlarından biri olan aktif kârlılığı (ROA) (net kâr/toplam aktifler) kullanılmıştır. Ancak yöneticiler tarafından kolayca manipüle edilebileceği konusunda muhasebe temelli ölçüt yöntemleri eleştirilmektedir (Cochran ve Wood, 1984: 47). Bu nedenle aktif kârlılık (ROA) oranı gibi muhasebe temelli ölçümlere göre yatırımcıların gelecek ile ilgili beklentilerini yansitan bir oran olarak kabul edilen Tobin-Q (Hoyt ve Liebenberg, 2011: 801) çalışmada ele alınan bir diğer finansal performans ölçüm yöntemi olmuştur.

Finansal performans değişkenlerinin kullanılan net kâr ve toplam aktiflere ilişkin verilerin hesaplanmasında, firmaların Kamuyu Aydınlatma Platformu'nda (KAP) (www.kap.gov.tr) yayınladıkları 2014-2018 dönemine ait yıllık bağımsız denetimden geçmiş finansal tablolarından yararlanılmıştır.

Bağımsız Değişken: Kurumsal itibarın ölçümlenmesinde kullanılan birçok yöntem bulunmaktadır. Ancak her yöntemin kendi bağlamında (ülke, kültür vd.) değerlendirilmesi gerekmektedir. Bu çalışmanın amacı, değişkenlerin yapısı ve kısıtları doğrultusunda kurumsal itibarın ölçümlenmesi için Brand Finance tarafından yayınlanan “Turkey 100: Türkiye'nin En Değerli Markalarının Yıllık Raporu” kapsamında yer alan marka değeri skorları kullanılmıştır ${ }^{3}$.

Aracı Değişken: İnovasyon kapasitesi değişkeni, firmaların yıllık raporları incelenerek elde edilmektedir. Çalışmanın amacı ve kısıtları dikkate alındığında bu çalışmada inovasyon kapasitesi Ar-Ge derinliği (Ar-Ge/Satışlar) ile ölçülmüştür (Filatotchev ve Piesse, 2009: 1267).

Kontrol Değişkenleri: Kontrol değişken olarak ele alınan firma büyüklüğü, toplam satışlar (Hitt vd., 1997; Contractor vd., 2007) ile ölçülmüştür. Bir diğer kontrol değişkeni olarak firma yaşı kullanılmıştır. Firma yaşı "firmanın faaliyete başladığı y1l ile ilgili (Cari) yıl arasındaki fark" ile hesap edilmektedir (Alparslan ve Aygün, 2013). Sektörün finansal performans üzerindeki etkisini tespit etmek amaciyla modele dâhil edilen sektör değişseni, imalat sektörü ise 1 değilse 0 değerini alan kukla değişkeni ile gösterilmektedir.

\subsection{Verilerin Analizi}

Kurumsal itibarın firmaların finansal performansları üzerindeki etkileri, 20142018 yıllarını kapsayan dönemde imalat ve diğer sektörlerde yer alan firmalar için test edilmiştir. Ekonometrik analizlerde genellikle üç farklı çeşit veri seti kullanılmaktadır. Bunlar; zaman serileri (time-series), yatay kesit (cross-section) ve panel veri yöntemidir (Gujarati, 2003; Pesaran, 2015). Panel veri yöntemi yatay kesit ve zaman serisi yöntemlerinin bileşiminden oluşmaktadır. Panel veri

\footnotetext{
${ }^{3}$ http://brandfinance.com.
} 
yöntemi kullanılarak örneklemdeki her veri için zaman bakımından çok sayıda gözlem ortaya çıkartılabilmektedir (Arellano, 2003: 1). Panel EKK sabit ve eğim katsayısının yatay ve zaman kesitler arasında sabit olduğu ve hata teriminin yatay ve zaman kesitler boyunca olan farklılıkları yakalayabildiği varsayılmaktadır. Tüm birimlerin verilerinin bir havuzda toplandığı ve bağımsız değişkenlerin bağımlı değişken üzerindeki etkilerinin analiz edildiği model Havuzlanmış Regresyon Modeli olarak tanımlanmaktadır (Baltagi, 2005: 11). Yapılan analizlerde birim ve zaman etki tespit edilememesi nedeniyle çalışmada panel EKK “Havuzlanmış Regresyon Modeli” kullanılmıştır.

Panel veri yöntemi aşağıdaki denklem yardımıyla gösterilebilir:

$$
\begin{gathered}
Y_{i t}=\alpha_{i t}+\beta_{1} X+\ldots \ldots \beta_{2} X_{i t}+\varepsilon_{i t} \\
i=1 \ldots . ., N ; t=1, \ldots . ., T
\end{gathered}
$$

1 numaralı denklemde $\mathrm{Y}$ bağımlı değişkeni, $\mathrm{X}$ bağımsız değişkenleri, $\mathrm{N}$ firma sayısın1, t zamanı ve $\varepsilon_{\text {it }}$ hata terimini göstermektedir.

Çalışmada 2014-2018 döneminde 35 firmayı kapsayan 175 adet gözlem değerine yer verilmiştir. Her bir bağımsız değişken için 2014-2018 yılları arasında kesintisiz bir veri seti oluşturularak dengeli panel kullanılmıştır. Araştırmada kullanılan model ve değişkenler ilgili literatür kapsamında belirlenmiştir. "İnovasyon kapasitesinin" varsayılmış mediation rolünü araştırmak için, Baron ve Kenny (1986) ve Judd ve Kenny (1981) tarafından açıklanan prosedürün uyarlanmış bir versiyonu kullanılmıştır. Çalışma modelini test etmek için Kurumsal itibarın firma performansı üzerindeki etkilerini $\mathrm{H}_{1}, \mathrm{H}_{2}$ ve $\mathrm{H}_{3}$ hipotezini test etmek üzere aşağıda ayrı ayrı modeller oluşturulmuştur. Kurumsal itibar ile finansal performans arasındaki doğrudan ilişkinin testi için oluşturulan model;

$$
\begin{aligned}
& \text { Model } 1 \text { FP }(\text { ROA })_{i t}=\alpha_{i t}+\beta_{1} L_{\text {LKI }} \dot{i t}_{i t}+\beta_{2} X_{i t}+\varepsilon_{i t} \\
& \text { Model } 2 \text { FP }(\text { Tobin-Q })_{i t}=\alpha_{i t}+\beta_{1} L_{\text {LKI }} \dot{i t}+\beta_{2} X_{i t}+\varepsilon_{i t}
\end{aligned}
$$

Model 1 'de; $\mathrm{i}=1 \ldots . ., \mathrm{N} ; \mathrm{t}=1, \ldots . ., \mathrm{T} ; \varepsilon_{\text {it }}$ hata terimini $\mathrm{L}$ ise ilgili değişkenin logaritmasının alındığını göstermektedir. Model 1'de FP (ROA ve Tobin-Q); finansal performansı LKİ, kurumsal itibarı, X; kontrol değişkenlerini (firma büyüklüğ̈̈, firma yaşı, sektör) temsil etmektedir.

Araştırma modelinde aracılık (Mediation) ilişkisi hipotezinin testi için Judd ve Kenny (1981: 207) ile Baron ve Kenny (1986: 1176-1177) tarafından ileri sürülen yol takip edilmiştir. Buna göre aracılık ilişkisi hipotezinin desteklenmesi için üç ayrı regresyon modeli test edilmiştir.

$$
\begin{gathered}
\text { Model } 3\left(\text { Yol c) FP }(\text { ROA/Tobin-Q })_{i t}=\alpha_{i t}+\beta_{1} \mathrm{LKI}_{\mathrm{it}}+\beta_{3} \mathrm{LIB}_{\mathrm{it}}+\beta_{4} \mathrm{LFY}_{\mathrm{it}}+\right. \\
\beta_{5} \text { Sektör }_{i t}+\varepsilon \text { it }
\end{gathered}
$$


Model 4 (Yol a) FP $(\text { ARS })_{i t}=\alpha_{i t}+\beta_{1}$ LKI $_{i t}+\beta_{3} \operatorname{LIB}_{i t}+\beta_{4} L_{F F}{ }_{i t}+\beta_{5} S_{\text {Sektör }}{ }_{i t}+$

$\varepsilon$ it

Model $5\left(\right.$ Yol b ve $\left.c^{\wedge}\right)$ FP $(\text { ROA/Tobin-Q })_{i t}=\alpha_{i t}+\beta_{1} L_{\text {I It }}+\beta_{2} \mathrm{ARS}_{\text {it }}+$

$$
\beta_{3} \mathrm{LIB}_{\mathrm{it}}+\beta_{4} \mathrm{LFY}_{\mathrm{it}}+\beta_{5} \text { Sektör }_{\text {it }}+\varepsilon \text { it }
$$

Tablo 2'de analizlerde kullanılan veri setine $(n=35)$ ilişkin tanımlayıcı istatistikler ve değişkenlerin aralarındaki korelasyonları ölçmek amacıyla yapılmış olan korelasyon tablosu bulguları verilmiştir. Değişkenlere ait korelasyon katsayıları

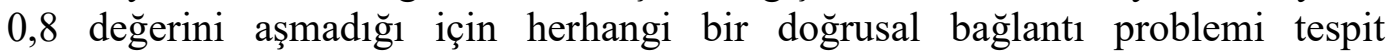
edilmemiştir. Korelasyon tablosu incelendiğinde Ar-Ge derinliği ile ROA $(0,24)$, firma yaşı ile ROA $(0,22)$, firma büyüklügüyle kurumsal itibar $(0,36)$, sektör ile ROA $(0,16)$, sektör ile firma yaşı $(0,32)$, firma yaşı ile ROA $(0,22)$, arasında $\mathrm{p}<0,01$ ve $\mathrm{p}<0,05$ anlam seviyesinde pozitif yönlü ilişkiler görülmektedir. TobinQ ile ROA (-0,54), Ar-Ge derinliği ile kurumsal itibar (-0,27), firma büyüklüğüyle Ar-Ge derinliği $(-0,31)$, firma büyüklüğüyle firma yaşı $(-0,26) \mathrm{p}<0,01$ anlam seviyesinde, sektör ile Ar-Ge derinliği $(-0,16)$, arasında $p<0,10$, sektör ile Tobin$\mathrm{Q}(-0,18)$, Ar-Ge derinliği ile Tobin-Q $(-0,36)$, arasında $\mathrm{p}<0,05$ anlam seviyesinde negatif yönlü ilişkiler görülmektedir. Bazı değişkenlere merkezileştirme işlemi uygulanmış ve analizlerde bağımsız, mediation ve kontrol değişkenler merkezileştirilmiştir.

Tablo 2: Değişenlere Ait Korelasyon Matrisi

\begin{tabular}{|c|c|c|c|c|c|c|c|c|c|}
\hline Değişkenler & Ortalama & $\begin{array}{c}\text { Standart Std. } \\
\text { Sapma }\end{array}$ & ROA & TOBIN-Q & ARS & Kİ & FY & IB & Sektör \\
\hline ROA & 0,054 & 0,07 & 1 & & & & & & \\
\hline TOBIN-Q & 0,061 & 0,197 & $-0,542^{* *}$ & 1 & & & & & \\
\hline ARS & 0,015 & 0,054 & $0,239^{* *}$ & $-0,196^{*}$ & 1 & & & & \\
\hline Kİ & $-0,018$ & 1,331 & 0,092 & 0,004 & $-0,267 * *$ & 1 & & & \\
\hline FY & 3,819 & 0,425 & $0,218^{*}$ & $-0,088$ & $-0,129$ & $-0,011$ & 1 & & \\
\hline & & & & & & - & & \\
FB & 21,678 & 1,498 & $-0,059$ & $-0,087$ & $-0,309^{* *}$ & $0,36^{* *}$ & $0,245^{* *}$ & 1 & \\
\hline Sektör & 0,555 & 0,498 & $0,16^{+}$ & $-0,176^{*}$ & $-0,159^{+}$ & $-0,025$ & $0,32^{* *}$ & 0,085 & 1 \\
\hline
\end{tabular}

\subsection{Bulgular}

Çalışmada kapsamında 35 firmanın 2014-2018 dönemlerine ilişkin verileri kullanılarak toplamda 175 adet gözlem analiz edilmiştir. Çalışmada kullanılan panel veri analizi panel EKK (Havuzlanmış Regresyon) modeline göre elde edilen sonuçlar her bir model (Mediation) için ayrı ayrı ele alınmış ve değerlendirilmiştir. Kurumsal itibar ve kontrol değişkenlerinin finansal performans üzerindeki etkisini gösteren panel veri analiz sonuçları Tablo 3 'te sunulmuştur. Elde edilen sonuçlara göre, Model 1'de kurumsal itibar değişkenin katsayıs1 0.008 olup \%10 seviyesinde istatistiksel olarak anlamliyken kurumsal itibar değişkeni Model 2'de istatistiksel olarak anlamlı tespit edilememiştir. Bu 
sonuç, kurumsal itibarın sadece finansal performansı göstergelerinden ROA'y1 pozitif olarak etkilediğini ortaya koymaktadır. Firma büyüklüğü, firma yaşı ve sektör olarak modelde yer alan kontrol değişkenlerin finansal performans üzerindeki etkilerini gösteren analiz sonuçları incelendiğinde, sadece sektör değişkeninin Model 2'te negatif ve \%5 seviyesinde istatistiksel olarak anlamlı olduğu görülmektedir. Öte yandan firma yaşının finansal performans üzerindeki etkisi tüm modellerde istatistiksel olarak anlamlı tespit edilememiştir. Ayrıca modele ilişkin F istatistikleri Model 1 ve Model 2'de anlamlı tespit edilmiştir. Elde edilen bulgular 1şığında, "Kurumsal itibar arttıkça finansal performans artacaktır" şeklinde ifade edilen $\mathrm{H}_{1}$ hipotezi kısmen (ROA) desteklenmiştir.

Tablo 3: Finansal performans (ROA ve Tobin-Q) ve Kurumsal İtibar için Regresyon Sonuçları

\begin{tabular}{|c|c|c|c|c|}
\hline \multirow[t]{2}{*}{ Değişkenler } & \multicolumn{2}{|c|}{ Model 1 ROA } & \multicolumn{2}{|c|}{ Model 2 Tobin-Q } \\
\hline & Katsayı & $t$ istatistiği & Katsayı & t istatistiği \\
\hline Kİ & $0,008^{+}$ & 1,948 & $-0,010$ & $-0,799$ \\
\hline FB & $-0,004$ & $-1,171$ & $-0,008$ & $-0,668$ \\
\hline FY & 0,001 & 0,143 & $-0,011$ & $-0,288$ \\
\hline Sektör & 0,016 & 1,368 & $-0,087 *$ & \\
\hline $\mathbf{R}^{2}$ & 0,03 & & 0,05 & \\
\hline F- testi: & $1,52^{+}$ & & $2,53^{*}$ & \\
\hline Gözlem Sayısı & 175 & & 175 & \\
\hline
\end{tabular}

İnovasyon kapasitesinin kurumsal itibar ve finansal performans arasındaki aracılık etkisini test etmek için yapılan mediation analiz sonuçları Tablo 4'te sunulmuştur. Tablo 4'te çalışmanın $\mathrm{H}_{2}$ ve $\mathrm{H}_{3}$ hipotezinin Baron ve Kenny (1986) tarafından önerilen varsayımlara ilişkin (direkt ve endirekt) bulguları içermektedir. Buna göre; kurumsal itibarın finansal performans üzerindeki etkisi (toplam etki yol c) ve kurumsal itibarın inovasyon kapasitesi üzerindeki etkisine (yol a) ve kurumsal itibar ve inovasyon kapasitesinin bir arada dâhil edildiği denklemde kurumsal itibarın finansal performans üzerindeki (direkt etki) etkisine (yol b ve $c^{\wedge}$ ) dair testleri ve bulguları içermektedir.

Tablo 4'te Model 1 de kurumsal itibarın finansal performans (ROA) üzerindeki toplam etki ele alınmaktadır. Elde edilen bulgularla, kurumsal itibarın finansal performans (ROA) üzerinde anlamlı ve pozitif yönlü bir etkisi olduğunu ortaya koymaktadır. (Model 1 (ROA: 0,007; $\mathrm{P}<0,01$ ). Kontrol değişkeni olarak ele alınan firma büyüklüğü (Model 1 (ROA: -0,003; P>,10), firma yaşı (ROA: 0,027; P>,10) ve sektör (ROA: 0,017; $\mathrm{P}>, 10$ ) değişkenlerinin finansal performans (ROA) üzerindeki etkileri anlamlı değildir. Model 4'te Kurumsal itibarın finansal performans (Tobin-Q) üzerindeki toplam etki ele alınmaktadır. Elde edilen bulgularla, kurumsal itibarın finansal performans (Tobin-Q) üzerinde anlamlı bir etkisi olmadığı tespit edilmiştir (Tobin-Q: 0,006; P>0,10). Kontrol değişkeni olarak ele alınan firma büyüklüğü (Tobin-Q: $-0,013$; $\mathrm{P}>0,10$ ), firma yaşı (Tobin- 
$\mathrm{Q}: \quad-0,031 ; \mathrm{P}>0,10$ ) sektör (Tobin-Q:-0,057; $\mathrm{P}>0,10$ ) değişkenlerinin firma performansı (Tobin-Q) üzerindeki etkisinin anlamlı olmadığı tespit edilmiştir.

Mediation analizinin ikinci varsayımı noktasında, Tablo 4 için kurumsal itibarın inovasyon kapasitesi üzerindeki etkisini ortaya koyan Model 2 ve Model 5 (ARS) incelendiğinde, ilişkinin anlamlı ve negatif yönde olduğu görülmektedir (Model 2 ve Model 5:-0,007; $\mathrm{P}<0,10$ ). Model 2 ve Model 5'te kontrol değişkeni olarak ele alınan firma büyüklüğü $(-0,010 ; \mathrm{P}<0,01)$, ve firma yaşı $(-0,022 ; \mathrm{P}<0,05)$ değişkenlerinin inovasyon kapasitesi üzerindeki etkilerinin anlamlı ve negatif yönlü olduğu görülmektedir. Bu bulgulara göre kurumsal itibar arttıkça inovasyon kapasitesinin azaldığı görülmektedir. Kurumsal itibarın inovasyon kapasitesini pozitif yönde etkileyeceğini varsayan "Kurumsal itibar arttıkça inovasyon kapasitesi artacaktır" şeklinde ifade edilen $\mathrm{H}_{2}$ hipotezi desteklenmemiștir. Tablo 4 'te yer alan bulguların mediator hipotezinin desteklenmesi için gerekli şartlardan biri olan inovasyon kapasitesinin finansal performans üzerine etkisinin (şekil 1; yol b) Model 3 (ROA): 0,450; P<0,01, ve Model 6 (Tobin-Q): -1,099; P<0,01 için istatistiksel olarak anlamlı olduğunu görmektedir. Kurumsal itibarın finansal performans üzerindeki direkt etkisinin (şekil 1; yol $\mathrm{c}^{\wedge}$ ) ROA için anlamlı ve pozitif (Model 3: 0,009; $\mathrm{P}<0,05$ ) ancak Tobin-Q için (Model 6: -0,002; P>,10) istatistiksel olarak anlamlı olmadığ 1 görülmektedir.

Elde edilen bulgular değerlendirildiğinde, Baron ve Kenny'nin (1986) varsayımları noktasında, kurumsal itibar ile finansal performans arasında bir toplam etkinin varlığı ROA için doğrulanmıştır. İkinci aşamada inovasyon kapasitesi ile kurumsal itibar arasındaki ilişkinin anlamlı (negatif) olduğu görülmektedir. Son varsayımda Tablo 4'te ROA değişkeni için Model 3'te elde edilen direkt etkinin anlamsız veya Model 1'de yer alan kurumsal itibarın finansal performans üzerindeki toplam etkisinden daha küçük olması beklenmektedir. Ancak hesaplanan direkt etkinin (ROA $c^{\wedge}$ : 0,009) katsayısının toplam etkiden (ROA c: 0,007$)$ daha büyük olduğu görülmektedir. İkisi arasındaki farkı (c- $\left.c^{\wedge}\right)$ ifade eden endirekt etkinin de negatif işaretli olduğu $(a \cdot b=-0,002)$ dikkat çekmektedir. Başka bir deyişle, direkt ve endirekt etkinin işaretlerinin farklı olduğu ve direkt etkinin katsayısının toplam etkinin katsayısından daha büyük olduğu görülmektedir. Verilerin analizi kısmında ayrıntılı olarak tanımlanan ve benzer bir örneği Cole vd., (2008) ve Okan vd.,'nin (2014) çalışmalarında da gözlenen bu durum, MacKinnon ve diğerlerine (2000) göre "suppression (önleyici) etki" olarak adlandırılmaktadır. İnovasyon üzerinden oluşan negatif işaretli endirekt etki $(-0,002)$, kurumsal itibarla inovasyon arasındaki toplam etkinin belirli bir kısmını oluşturmakta ve bu durum önleyici bir etki olarak işlev görmektedir. Tobin-Q değişkeni için Model 6'da kurumsal itibar ile finansal performans arasında bir toplam etkinin varlığı tespit edilememiştir. Söz konusu durumda Tobin-Q değişkeni için aracılık ilişkisinden bahsedilememektedir. Bu bulgular 1şığında "İnovasyon kapasitesi, kurumsal itibar ve finansal performans arasındaki ilişkide aracı (Mediator) değişken olarak rol oynayacaktır” şeklinde ifade edilen $\mathrm{H}_{3}$ hipotezi kısmen (ROA) desteklenmiştir. 
Tablo 4: Kurumsal İtibar ve Finansal Performans (ROA/Tobin-Q) İlişkisinde İnovasyon Kapasitesinin Mediator Etkisi için Regresyon Sonuçları

\begin{tabular}{|c|c|c|c|c|c|c|}
\hline & \multicolumn{3}{|c|}{ Bağımlı değişken ROA } & \multicolumn{3}{|c|}{ Bağımlı değişken Tobin-Q } \\
\hline & Model 1 (ROA) & $\begin{array}{c}\text { Model } 2 \\
\text { (ARS) }\end{array}$ & Model 3 (ROA) & $\begin{array}{c}\text { Model } 4 \\
\text { (Tobin-Q) }\end{array}$ & $\begin{array}{c}\text { Model } 5 \\
\text { (ARS) }\end{array}$ & $\begin{array}{c}\text { Model } 6 \\
\text { (Tobin-Q) }\end{array}$ \\
\hline \multicolumn{7}{|c|}{\begin{tabular}{|l|} 
Kontrol değişkenleri \\
\end{tabular}} \\
\hline FB & $-0,003$ & $-0,010 * *$ & 0,001 & $-0,013$ & $-0,010 * *$ & $-0,025^{+}$ \\
\hline FY & 0,027 & $-0,022^{+}$ & $0,03 *$ & $-0,031$ & $-0,022^{+}$ & $-0,055$ \\
\hline Sektör & 0,017 & $-0,009$ & $0,020^{+}$ & $-0,057$ & $-0,009$ & $-0,068^{+}$ \\
\hline \multicolumn{7}{|c|}{ Bağımsız değișken } \\
\hline KI & $0,007 * *$ & $-0,007^{+}$ & $0,009^{*}$ & 0,006 & $-0,007^{+}$ & $-0,002$ \\
\hline \multicolumn{7}{|c|}{ Aracı Değişken } \\
\hline ARS & & & $0,450 * *$ & & & $-1,099 * *$ \\
\hline & & & & & & \\
\hline $\mathrm{R} 2$ & 0,07 & 0,17 & 0,17 & 0,041 & 0,17 & 0,12 \\
\hline F- testi: & $2,45^{*}$ & $6,60 * *$ & $5,31 * *$ & 1,38 & $6,60 * *$ & 3,39 \\
\hline Gözlem Sayıs1 & 135 & 135 & 135 & 135 & 135 & 135 \\
\hline
\end{tabular}

Gerçekleştirilen araştırmanın sonuçları Tablo 5'te özetlenmektedir. Tablo 5 incelenecek olursa araştırma kapsamında gerçekleşmesini beklediğimiz ilişkilerin gerçekleştiği, ortaya çıkan etkilerin birçoğunun bağımlı değişkenlerin tümünde anlamlı olmaması nedeniyle bazı hipotezlerin kısmen kabul edildiği söylenilebilir.

Tablo 5: Araştırma Hipotezleri Sonuçları Özeti

\begin{tabular}{|c|c|c|c|}
\hline Hipotezler & Sonuçlar & \multicolumn{2}{|c|}{ Finansal Performans } \\
\hline & & ROA & Tobin-Q \\
\hline \multirow[t]{2}{*}{$\begin{array}{l}\mathrm{H}_{1}: \text { Kurumsal itibar finansal performans } \\
\text { üzerinde pozitif yönlü bir etkiye sahiptir. }\end{array}$} & $\begin{array}{c}\text { K1smen } \\
\text { desteklenmistir }\end{array}$ & $(++)^{+}$ & 0 \\
\hline & & \multicolumn{2}{|c|}{ ARS } \\
\hline \multirow[t]{3}{*}{$\begin{array}{l}\mathrm{H}_{2} \text { : Kurumsal itibar, inovasyon kapasitesi } \\
\text { üzerinde pozitif etkiye sahiptir. }\end{array}$} & Desteklenmemiştir & \multicolumn{2}{|c|}{$(-)^{+}$} \\
\hline & & \multicolumn{2}{|c|}{ Finansal Performans } \\
\hline & & ROA & Tobin-Q \\
\hline $\begin{array}{l}\text { H3: İnovasyon kapasitesinin, kurumsal itibar ve } \\
\text { finansal performans arasındaki ilişkide arac1 } \\
\text { (Mediator) değişken olarak rol oynar. }\end{array}$ & $\begin{array}{c}\text { Kismen } \\
\text { Desteklenmiştir }\end{array}$ & $(++) *$ & 0 \\
\hline
\end{tabular}

\section{Tartışma ve Sonuç}

Kurumsal itibar ile finansal performans arasındaki ilişkide inovasyon kapasitesinin aracı etkisini ele alan bu çalışmanın, sunmuş olduğu kavramsal model ve elde edilen analiz bulguları neticesinde önemli katkılar sunduğu söylenilebilir. Maddi olmayan soyut nitelikli firma içi bir kaynak olarak değerlendirilen kurumsal itibar firmaların rakipleri karşısında rekabet avantajı elde etmeleri noktasında stratejik bir varlık olma özelliği taşımaktadır. Son yıllarda ekonomi alanında yaşanan paradigma değişimi firmaların faaliyetlerinde bir değişime neden olmuş ve kurumsal itibarın önemi dikkat çekmiştir. Dolayısıyla bu çalışmada kaynak temelli yaklaşımın kavramsal arka planıyla kurumsal itibarla finansal performans arasındaki direkt etkiye ek olarak inovasyon 
kapasitesi üzerinden meydana gelebilecek bir endirekt etkisinin olup olmayacağı araştırılmıştır.

Çalışma bulguları, kurumsal itibarın finansal performans üzerinde pozitif yönde etkisi olduğu sonucunu ortaya koymuştur. Ancak kurumsal itibarla finansal performans göstergelerinden sadece ROA üzerinde pozitif yönde anlamlı bir ilişki elde edilirken piyasa temelli ölçüm yöntemi olan Tobin-Q ile anlamlı ilişkilerin tespit edilememiştir. Çalışma bulguları literatür ile uyumlu gözükmektedir (Yünsüz, 2020). Uluslararası literatürde pek çok çalışma kurumsal itibarla performans arasındaki ilişkiyi incelemiş ve daha yüksek kurumsal itibarın daha yüksek firma performansına sebep olduğunu; itibarın finansal performans ile pozitif olarak ilişkili olduğu sonucuna ulaşmıştır (Boyd, vd., 2010; Rindova, vd., 2010). Örneğin, Roberts ve Dowling'in (2002), 1994-1998 yılları arasında Fortune'un raporlarını kullanarak kurumsal itibar ve finansal performans arasındaki ilişkiyi incelemiş ve görece iyi itibara sahip firmaların avantajlarını daha iyi sürdürdüklerini bulmuştur. Piyasa temelli ölçüm yöntemi olarak kullanılan Tobin-Q içinde istatistiksel olarak anlamlı bir ilişki elde edilememiş olmasının olası bir açıklaması; Tobin-Q'nun muhasebe uygulamalarındaki değişikliklere daha az hassas ve aktif kârlılık oranı (ROA) gibi diğer performans ölçümlerinin aksine yatırımcıların gelecekle ilgili beklentilerini yansıtan bir oran olarak kabul edilmesine (Hoyt ve Liebenberg, 2011: 801) karşın, Wernerfelt ve Montgomery (1988) tarafından gerçekleştirilen çalışmada Tobin-Q oranına dair çeşitli firmaların finansal yöneticileri ile yapılan görüşmelerde, günlük yaşamda Tobin-Q'ya fazlaca güvenilmediği sonucuna ulaşılmıştır. Bu durumu TobinQ'nun hem kendisinin hem de birçok yönünün fazla bilinmemesinden kaynaklanabileceği gibi ihtiyaç duyulduğunda Tobin-Q verisinin zamanında ve hassas olarak sağlanamaması ve üstelik daha yaygın olarak bilinen değişkenlerle kıyaslandığında verilerinin kısıtlı olmasıyla açıklanabilmektedir (Chung ve Pruitt, 1994: 70). Türkiye gibi gelişmekte olan ekonomilerde veri temini ve güvenilirliğinde yaşanılan sorunlar, kurumsal itibarın Tobin-Q üzerinde anlamlı bir ilişki elde edileme nedeni olarak düşünülebilir. Benzer sonuçlar; Yünsüz (2020), tarafından yapılan çalışmada aile sahipliği yüzdesindeki farklılıkların işletmenin finansal parametreleriyle (hisse değeri getiri değeri, Tobin-Q, ROE) herhangi bir anlamlı ilişkisi olmadığı sonucunu elde etmiştir.

Kaynak temelli yaklaşımın kapsamında, kurumsal itibarın sonuçlarının kârlılık olduğu ve firmaların aktif kârlılıklarında bir artış sağlayacağına yönelik varsayımıyla firmaların görünür olmayan kaynak ve varlıklarının performansı arttıran önemli bir rekabet aracı olduğu (Carmeli ve Tishler, 2014:1267) düşünüldügünde örneklemde yer alan firmaların kurumsal itibarlarının aktif kârlılıklarında olumlu bir sonuç yaratması olağandır. Kurumsal itibarla finansal performans arasındaki ilişkinin pozitif yönde istatistiksel olarak anlamlı olduğu noktasında kurumsal itibarın stratejik avantaj sağlayan kaynak olma özelliğinden yola çıkarak teorinin temel savlarının geçerli olduğu söylenilebilir. 
Çalışmada ayrıca kurumsal itibarla inovasyon kapasitesi arasında pozitif yönde anlamlı bir ilişki gerçekleşmesi beklenirken analizler sonucunda kurumsal itibarla inovasyon arasında anlamlı bir ilişki tespit edilmiş ancak ilişki beklenilen yönde gerçekleşmemiştir. Firma itibarının inovasyon üzerinde pozitif etkiye sahip olmamasının olası bir açıklaması; yüksek itibara sahip firmaların, halihazırda kurulmuş olan itibarı korumak için zaman içinde tutarlı performans sunmaya odaklanmaları ve genellikle risk azaltma stratejileri uygulamaları (Petkova vd., 2014: 425) nedeniyle ilişki beklenilen yönde gerçekleşmiş olabilir. Perrin (2002), inovasyonun hangi aktivitenin işe yaradığı, kimin fayda sağlayacağ faydaların ne zaman gerçekleşeceği bakımından riskli ve öngörülemez olduğunu ileri sürmektedir. Benzer şekilde Peters'a (1991) göre inovasyon, tehlikeli bir süreçtir. İnovasyon faaliyetlerinin risk oranın yüksek olması firmaların düşük düzeyde yenilikçi davranış sergilemesine yol açabilmektedir. Elde edilen çalışma sonuçlarının literatürle de uyumlu olduğu gözlemlenmektedir. Örneğin Steenvoorde (2017), firmanın inovasyon davranışları üzerinde kurumsal itibar ve CEO ününün etkilerine yönelik yaptığı çalışmada kurumsal itibarın firma inovasyon faaliyetlerini olumsuz yönde etkilediği sonucuna ulaşmıştır. Padgett ve Leite (2012), yaptıkları araştırma sonucunda Ar-Ge yoğunluğuyla kurumsal itibar arasında negatif yönlü ilişki olduğu sonucunu elde etmişlerdir. Elde edilen sonuçlar teorik çerçevede değerlendiğinde, kaynak temelli yaklaşım kapsamında firmanın soyut kaynakları içerisinde değerlendirilen kurumsal itibar ve inovasyon firmalara sürdürülebilir rekabet avantajı yaratma noktasında önemli olan iki temel değişkendir. Ancak analiz sonuçlarına göre firmaların kurumsal itibarı inovasyondan daha değerli bir kaynak olarak gördükleri ve riskli algıladıkları inovasyonu daha düşük seviyelerde gerçekleştirdikleri düşünülmektedir. $\mathrm{Bu}$ noktada kaynak temelli yaklaşım iki değişkenin de nadir ve değerli olduğunu ifade ettiği savıyla sonuçlar desteklenmektedir.

Elde edilen negatif ilişkiye yönelik kaynak temelli yaklaşımın genel savlarına ek olarak kurumsal bağlamın değerlendirilmesi noktasının da ele alınması gerektiği düşünülebilmektedir. Çünkü Petkova vd., (2014: 424) ABD risk sermayesi firmalarının 1990'dan 2008'e kadar temiz enerji sektöründeki yatırımlarına ilişsin analizlerinde, kurumsal itibarı yüksek firmaların gelişmekte olan sektöre yatırım yapma olasılıklarının daha yüksek olmasına rağmen risk azaltma stratejilerini daha kapsamlı bir şekilde kullandıkları sonucunu elde etmişlerdir. Bu durumun firmaların içinde bulundukları sektörün yapısından kaynaklandığını ve firmaların yatırım kararlarını hem doğrudan hem de firma itibarı ile etkileşimi yoluyla daha da etkileyebildiklerini ifade etmişlerdir. Farklı kurumsal bağlamlarda farklı sonuçlar elde edilebilmektedir. Ülke bağlamı ve ülkede yerleşik durumda olan kültürel özellikler de inovasyon üzerinde etkili olan kilit faktörlerden bir diğeri olmaktadır (Mitchell vd., 2000; Tylecote, 1996). Temelde kültürel farklılıklar hem inovasyon girdisi süreci hem de oluşan yeniliklerin ticarileştirilmesi noktalarında önemli bir rol oynamakta ve inovasyona yönelik çalışmaları etkilemektedir (Shane, 1993). Bu nedenle firmaların kurumsal itibarı inovasyondan daha değerli 
bir kaynak olarak görmelerine ve risk azaltma stratejisi uygulayarak inovasyon faaliyetlerini gerçekleştirmemelerine neden olabilmektedir. Çalışmada kurumsal itibarla finansal performans arasındaki ilişkide inovasyonun aracı etkisine yönelik gerçekleştirilen analizler sonucunda inovasyonun kurumsal itibarla finansal performans (ROA) arasındaki ilişkide önleyici bir etkisi olduğu sonucu elde edilirken, Tobin-Q değişkeni için toplam etkinin oluşmaması nedeniyle aracı etkiye yönelik bir sonuç elde edilememiştir. $\mathrm{Bu}$ nedenle aracı etkinin varlığını ifade eden $\mathrm{H}_{3}$ hipotezi kısmen desteklenmiştir.

Araştırma modelinde, kurumsal itibar ile finansal performans arasındaki ilişki ele alınırken inovasyon faaliyetlerinin ilişkiye nasıl aracılık edeceğinin de ortaya konulması amaçlanmıştır. Firmaların kurumsal itibarının finansal performans üzerinde meydana getireceği sonuçlar önemli ölçüde firmaların inovasyon faaliyetleri gerçekleştirmeleri üzerinden ortaya çıkacaktır. Bu bağlamda firmaların başarısı veya başarısızlıkları stratejik bir karar olan inovasyon faaliyetlerinin yapılmasına bağlı olacaktır. Bu noktada iki farklı durum ortaya çıkabilir. İlk olarak firmaların kurumsal itibarlarının getirilerinden olumlu olarak faydalanıp stratejik bir karar olan inovasyon çalışmalarına yönelterek elde edeceği olumlu performans, kurumsal itibarın firmanın performansı üzerindeki direkt etkisinden daha fazla bir toplam etkinin meydana gelmesini sağlayabilir. İkinci olarak ise firmaların yüksek kurumsal itibarlarına güvenip risk azaltma stratejileri uygulayarak inovasyon faaliyetlerinden kaçınmaları sonucunda, kurumsal itibarla finansal performans arasındaki toplam etkinin düşmesine yol açacak önleyici bir etkiye neden olabilir.

Bir aracı etkinin olup olmadığının değerlendirilmesi noktasında elde edilen bulgular değerlendirildiğinde inovasyonun ilişkide "önleyici" bir etkiye sahip olduğu görülmektedir. Burada inovasyonun aracı etkisinin önleyici nitelik taşımasının sebebi kurumsal itibarla inovasyon arasındaki negatif yönlü ilişkinin varlığı olmaktadır. Kurumsal itibarla inovasyon arasında gerçekleşen negatif yönlü ilişki daha önce değerlendirildiği gibi literatürle uyumludur. Kurumsal itibar ile finansal performans arasında gerçekleşen pozitif yönlü ilişki inovasyon faaliyetlerine yönelik kısa vadeli uygulamalar sonucunda etkilenmese de uzun vadede uygulanan risk azaltma stratejileri düşük seviyelerde gerçekleştirilen inovasyon faaliyetlerinin kurumsal itibar ile finansal performans arasindaki ilişkiyi azaltıcı bir rol üstlenecektir. Petkova vd., (2014: 425) itibarı yüksek bir firmanın risk azaltma stratejileri kullanarak yerleşik itibarını korumak isteyebileceğini ileri sürmektedir. Bu ilişkinin açıklanması noktasında kaynak temelli yaklaşıma ek olarak bağlam da dikkate alınması gereken önemli bir konu olmaktadır. Türk iş sistemindeki firmaların büyük ölçüde mali kuruluşlar gibi işledikleri, faaliyetlerinde kısa dönemli kar maksimizasyonuna yönelik ticari kaygıların hemen hemen her zaman üretimde yenilik ve verimliliği arttırmak ve uluslararası planda rekabet gücü kazanmak gibi amaçların önüne geçtiği görülmektedir (Buğra, 2016: 69). Bu noktada firmaların inovasyon faaliyetlerini daha riskli algılamaları ve kısa dönemli kârlılık düşünceleri nedeniyle daha çok 
finansal performans sürdürme stratejileri uygulamalarının uzun dönemde kurumsal itibarla finansal performans arasındaki ilişkinin zayıflamasına neden olacağı söylenilebilir.

Elde edilen sonuçların kurumsal itibarla finansal performans arasındaki ilişkinin boyutlarının/yönünün teorik bir zeminle ele alınarak açıklığa kavuşturulmasıyla stratejik yönetim literatürü başta olmak üzere literatüre katkı sağlayacağı düşünülmektedir. Kurumsal itibarla finansal performans arasındaki ilişki, genellikle öncül çalışmalarda doğrudan bir ilişki olarak ele alınmıştır ancak aralarındaki ilişkinin yönü ve büyüklüğü konusunda farklı sonuçlar elde edilmiştir. Bu çalışmada ise kurumsal itibarın finansal performans üzerindeki toplam ve direkt etkilerine ek olarak inovasyon faaliyetleri üzerinden ortaya çıkabilecek bir endirekt etkisi geniş bir perspektiften ele alınmıştır. Kurumsal itibar ve finansal performans arasındaki ilişkide aracı değişken olarak rol alacağı düşünülen inovasyon kapasitesinin modele dâhil edilmesiyle, kurumsal itibarla finansal performans arasındaki ilişkiyi doğrudan ele alan ilgili literatürde ortaya çıkan farklı bulguların açıklanması noktasında önemli farklı bir bakış açısı sunulmaktadır. Firmaların kurumsal itibarlarını doğru yönetmeleri sonucunda finansal performans göstergelerinde olumlu çıktılar elde edebilecekleri sonucu literatüre kazandırılmıştır. Kurumsal itibar ile inovasyon arasındaki direkt etki ve kurumsal itibarla finansal performans arasındaki ilişkide inovasyonun önleyici etkisine yönelik elde edilen sonuçlar özellikle Türkiye bağlamında önemli çıktılara işaret etmektedir. $\mathrm{Bu}$ durum iş ve ekonomi dünyasında yer alan firmaların inovasyon faaliyetlerine yönelik bakış açılarının kısa vadeli kârlılık peşinde koşmak yerine uzun vadede risk alma stratejileri uygulayarak elde edebilecekleri finansal performans çıktılarının boyutlarına yönelik önemli bir görüntü sunmaktadır.

Araştırmanın bulgularının tartışması noktasında araştırma sonuçları ve süreci üzerinde etkili olacağı düşünülen birtakım kısıtların da göz önüne alınması gerekmektedir. Türkiye'de konuya ilişkin sınırlı sayıda yapılan çalışmaların yanında güncel verilerden yararlanılarak yapılan çalışmada 2014-2018 yıllarına ait veriler kullanılmış ve bu yıllarda süreklilik gösteren 35 firma verisinden yararlanılmıştır. Özellikle Türkiye'de verilerine ulaşılabilen firma sayısı sınırlı olması nedeniyle örneklem BİST'de koteli olan firmalarla sınırlı tutulmuştur. Bir başka kısıt, firmaların itibar skorlarına yönelik verilerin elde edilmesi noktasıdır. Ayrıca Türkiye gibi gelişmekte olan ülkelerde veri teminindeki sorunlar ve özellikle inovasyon yapan firmalara yönelik verilerin temininin az ve karmaşı olması da bir diğer kısıttır.

Gelecek çalışmalar için öneriler noktasında özellikle kurumsal itibarın ölçümünde hazır bir ölçümün kullanılması yerine nitel veri toplama yöntemleri aracılığıyla kurumsal itibara yönelik daha geniş bir veri seti oluşturulabilir. Ayrıca modele inovasyon faaliyetleri açısından firmaların teknoloji bağlılığı olan/olmayan şeklinde bir bağımsız değişken olarak eklenmesi ile analizler zenginleştirilebilir. 
Ek olarak çalışma modelinde önemli bir etkisi olacağı düşünülen inovasyonun Türkiye bağlamındaki ele alınış şekli ve firmaların inovasyonu riskli olarak değerlendirmeleri hususunda elde edilen sonuçlarda kurumsal bağlamın etkisi ve kurumsal teorinin varsayımlarının göz önüne alınması gerekmektedir. Bu șekilde hem modelin hem de Türkiye bağlamının daha net bir şekilde açılanabileceği düşünülmektedir.

\section{Kaynakça}

Alparslan, A. ve Aygün, M. (2013) Kurumsal Sosyal Sorumluluk ve Firma Performans1. S.D.Ü. I.I.B.F. Dergisi, 18(1), 435-448.

Arellano, M. (2003). Panel Data Econometrics Advanced Texts in Econometrics, Great Britain, Oxford University Press.

Argenti, A. P. ve Druckenmiller, B. (2004). Reputation and the Corporate Brand. Corporate Reputation Review, 6(4), 368-374.

Aslan, Y. ve Aygün, M. (2019). İnovasyonun Firma Performansı Üzerine Etkisi: Bistte İmalat Sektöründe Faaliyet Gösteren Firmalar Üzerine Bir İnceleme. Anemon Muş Alparslan Üniversitesi Sosyal Bilimler Dergisi, 7(6), 91-109.

Bala, Y. ve Utluc, N. (2020). İnovasyon ve Kurumsal Sosyal Sorumluluğun Kurumsal İmaj Üzerindeki Etkisi: Bankacılık Sektöründe Bir Uygulama. Ylldız Sosyal Bilimler Enstitüsü Dergisi, 4(8), 162-179.

Baltagi, H. B. (2005). Econometric Analysis of Panel Data. 3. Bask1, England: John Wiley \& Sons Ltd.

Barney, J. (1991). Firm Resources and Sustained Competitive Advantage. Journal of Management, 17 (1): 99-120.

Barney, J. (2002). Gaining and Sustaining Competitive Advantage, Reading, MA: Addison Wesley.

Baron, M. R. ve Kenny, A. D. (1986). The Moderator-Mediator Variable Distinction in Social Psychological Research: Conceptual, Strategic, and Statistical Conciderations. Journal of Personality and Social Psychology, 51(6), $1173-1182$.

Beatty, R. P. ve Ritter, J. R. (1986). Investment Banking, Reputation, and Underpricing of Initial Public Offerings. Journal of Financial Economics, 15, 213-232.

Ben-Zion, U. (1978). The İnvestment Aspect of non-Production Expenditures: an Empirical Test. Journal of Economics and Ž. Business Spring , 30 (3) 224229.

Berens, G. ve Van Riel, C. (2004). Corporate Associations in the Academic Literature: Three Main Streams of Thought in the Reputation Measurement Literature. Corporate Reputation Review, 7 (2), 161-178. 
Boyd, B. K., Bergh, D. D. ve Ketchen Jr, D. J. (2010). Reconsidering the Reputation Performance Relationship: A Resource-Based View.Journal of Management, 36(3), 588-609.

Buğra, A. (2016). Devlet ve İş Adamları, İletişim Yayınları, İstanbul.

Carmeli, A. ve Tishler, A. (2014). The Relationships Between Intangible Organizational Elements and Organizational Performance. Strategic Management Journal, 25 (13), 1257-1278.

Chung, K. H. ve Pruitt, S. W. (1994). A Simple Approximation of Tobin's q. Financial Management, 70-74.

Clark, K. B. ve Griliches, Z. (1984). Productivity Growth and R\&D at the Business Level: Results from the PIMS Data Base. In $R \& D$, Patents, and Productivity. University of Chicago Press. 393-416

Cochran, P. L. ve Robert A. W. (1984). Corporate Social Responsibility and Financial Performance. Academy of Management Journal, 27(1), 42-56.

Cole, M. S., Walter, F. ve Bruch, H. (2008). Affective Mechanisms Linking Dysfunctional Behavior to Performance in Work Teams: A Moderated Mediation Study. Journal of Applied Psychology, 93(5), 945.

Contractor, F. J., Kundu, S. K. ve Hsu, C. C. (2003). A Three-stage Theory of International Expansion: The Link Between Multinationality and Performance in the Service Sector. Journal of International Business Studies, 34(1), 5-18.

Damanpour, F., Walker, R. M. ve Avellaneda, C. N. (2009). Combinative Effects of İnnovation Types and Organizational Performance: A Longitudinal Study of Service Organizations. Journal of Management Studies, 46(4), 650-675.

De Castro, G. M., López, J. E. N. ve Sáez, P. L. (2006). Business and Social Reputation: Exploring the Concept and Main Dimensions of Corporate Reputation. Journal of Business Ethics, 63(4), 361-370.

De Castro, G. M., Sáez, P. L. ve López, J. E. N. (2004). The Role of Corporate Reputation in Developing Relational Capital. Journal of Intellectual Capital.

Deephouse, D. L . (2000). Media Reputation as a Strategic Resource: An Integration of Mass Communication and Resource-Based Theories. Journal of Management, 26(6), 1091-1112.

Del Canto, J. G. ve Gonzalez, I. S. (1999). A Resource-Based Analysis of the Factors Determining a Firm's R\&D Activities. Research Policy, 28(8), 891905.

Dowling, G. R. (2000). Creating Corporate Reputations: Identity, Image and Performance. OUP Oxford. 
Eberl, M. ve Schwaiger, M. (2005). Corporate Reputation: Disentangling the Effects on Financial Performance. European Journal of Marketing, 39(7/8), 838-854.

Ersöz, F. (2009). Avrupa İnovasyon Göstergeleri (EIS) Işığında Türkiye'nin Konumu. Itü̈dergisi/b, 6(1), 3-16

Fang, L. H. (2005). Investment Bank Reputation and the Price and Quality of Underwriting Services. The journal of finance, 60(6), 2729-2761.

Filatotchev, I. ve Jenifer P. (2009). R\&D, Internationalization and Growth of Newly Listed Firms: European Evidence. Journal of International Business Studies, 40(8), 1260-1276.

Flanagan, D. J ve O'Shaughnessy, K. C. (2005). The Effect of Layoffs on Firm Reputation. Journal of Management, 31(3), 445-463.

Fombrun, C. J ve Shanley, M. (1990). What's in a Name? Reputation Building and Corporate Strategy. Academy of Management Journal, 33(2), 233-258.

Fombrun, C. J. (1996), Reputation :Realizing Value From The Corporate Image, Harvard Business School Press, Boston.

Friar, J. H. (1995). Competitive Advantage Through Product Performance Innovation in a Competitive Market. Journal of Product Innovation Management, 12(1), 33-42.

Galende, J. ve De La Fuente, J. M. (2003). Internal Factors Determining a Firm's İnnovative Behaviour. Research Policy, 32(5), 715-736.

Gopalakrishnan, S. (2000). Unraveling the Links Between Dimensions of Innovation and Organizational Performance. The Journal of High Technology Management Research, 11(1), 137-153.

Gray, E. R. ve Balmer, J. M. T. (1998). Managing Corporate İmage and Corporate Reputation. Long Range Planning, 31(5), 695-702.

Griliches, Z. (1979). Issues in Assessing the Contribution of Research and Development to Productivity Growth. The Bell Journal of Economics, 92-116.

Gujarati, D. N. (2003). Basic Econometrics, 4. Bask1, New York: McGraw-Hill Companies.

Gunday, G., Ulusoy, G., Kilic, K. ve Alpkan, L. (2011). Effects of Innovation Types on Firm Performance. International Journal of Production Economics, 133(2), 662-676.

Güleş, H. K. ve Bülbül, H. (2004). Toplam Kalite Yönetiminin İșletmelerde Yenilik Çalışmalarına Katkısı. Gazi Üniversitesi İktisadi ve İdari Bilimler Fakültesi Dergisi, 6(1), 115-129. 
Hall, R. (1992). The Strategic Analysis of İntangible Resources. Strategic Management Journal, 13(2), 135-144.

Harmancıoğlu, N. (2012). İnovasyon Süreci: Yeni Ürün Geliştirmede İnovasyon Literatürünün Teorik Meta Analizi. Girişimcilik ve İnovasyon Yönetimi Dergisi, 1(1), 1-23.

Hayes, A. F. (2009). Beyond Baron and Kenny: Statistical Mediation Analysis in the new Millennium. Communication Monographs, 76(4), 408-420.

Henard, D. H ve Dacin, P. A. (2010). Reputation for Product Innovation: Its impact on Consumers. Journal of Product Innovation Management, 27(3), 321-335.

Hitt, M. A., Hoskisson, R. E., ve Kim, H. (1997). International diversification: Effects on innovation and firm performance in product-diversified firms. Academy of Management journal, 40(4), 767-798.

Hitt, M. A., Ireland, R. D., Camp, S. M. ve Sexton, D. L. (2001). Strategic entrepreneurship: Entrepreneurial strategies for wealth creation. Strategic Management journal, 22(6-7), 479-491.

Hoyt, R. E. ve Liebenberg, A. P. (2011). The Value of Enterprise Risk Management. Journal of Risk and Insurance, 78 (4), pp. 795-822.

Hull, C. E. ve Rothenberg, S. (2008). Firm Performance: The Interactions of Corporate Social Performance with Innovation and Industry Differentiation. Strategic Management Journal, 29(7), 781-789.

Hult, G. T. M., Snow, C. C. ve Kandemir, D. (2003). The Role of Entrepreneurship in Building Cultural Competitiveness in Different Organizational Types. Journal of Management, 29(3), 401-426.

İnceöz, S. (2015). Kurumsal Sosyal Sorumluluğun Kurumsal İtibara Etkileri: Otel İsletmelerine Yönelik Bir Araştırma. Türk Hava Kurumu Üniversitesi, Sosyal Bilimler Enstitüsü, İşletme Anabilim Dalı, Yüksek Lisans Tezi.

Judd, C. M ve Kenny, D. A. (1981). Estimating the Effects of Social Intervention, CUP Archive.

Kadıbeşegil, S. (2006). İtibar Yönetimi, Medicat Yayınları, İstanbul

Kim, W. C. ve Mauborgne, R. (2005). Blue Ocean Strategy: How to Create Uncontested Market Space and Make Competition Irrelevant, Harvard Business Press, Boston.

Kowalczyk, S. J ve Pawlish, M. J. (2002). Corporate Branding Through External Perception of Organizational Culture. Corporate Reputation Review, 5(2), 159-174. 
Kuratko, D. F., Ireland, R. D., Covin, J. G. ve Hornsby, J. S. (2005). A Model of Middle-Level Managers' Entrepreneurial Behavior. Entrepreneurship Theory and Practice, 29(6), 699-716.

Lee, J. ve Roh, J. J. (2012). Revisiting Corporate Reputation and Firm Performance Link. Benchmarking: An International Journal, 19(4), 649-664.

Li, H. G., Chen, Z. W. ve Ma, G. X. (2016). Corporate reputation and performance: A legitimacy perspective. Entrepreneurial Business and Economics Review, 4(3), 181.

MacAlister, J. (2016). Risky Strategy: Understanding Risk to Improve Strategic Decisions. Bloomsbury Publishing, London.

MacKinnon, D. P., Krull, J. L. ve Lockwood, C. M. (2000). Equivalence of the Mediation, Confounding and Suppression Effect. Prevention science, 1(4), 173-181.

Mansfield, E. (1961). Technical Change and The Rate Of Imitation. Econometrica: Journal of the Econometric Society, 29(4), 741-766.

Mansfield, E. (1968). The Economics of Technological Change, Norton, New York.

Marr, B. (2005). Management Consulting Practice on Intellectual Capital Editorial and Introduction to Special Issue. Journal of Intellectual Capital, 6 (4), 469473.

Mathieu, J. E. ve Taylor, S. R. (2006). Clarifying Conditions and Decision Points for Mediational Type Inferences in Organizational Behavior. Journal of Organizational Behavior, 27, 1031-1056.

Metcalfe, J. S. (1998). Evolutionary Economics and Creative Destruction. Routledge, London.

Mishina, Y., Dykes, B. J., Block, E. S. ve Pollock, T. G. (2010). Why "Good" Firms do Bad Things: The Effects of High Aspirations, High Expectations, and Prominence on the İncidence of Corporate İllegality. Academy of Management Journal, 53(4), 701-722.

Mitchell, R. K., Smith, B., Seawright, K. W., \& Morse, E. A. (2000). CrossCultural Cognitions and the Venture Creation Decision. Academy of management Journal, 43(5), 974-993.

Moore, G. A. (1999). Crossing the Chasm: Marketing and Selling Disruptive Products to Mainstream Customers, HarperBusiness, New York.

Okan, T., Sarı, S., ve Nas, T. İ. (2014). Yönetim Kurulu Papısı İle Finansal Performans Aarasındaki İlişkide Uluslararasılaşma Çeşitlenmenin Aracılık Etkisi. İstanbul Üniversitesi İşletme Fakültesi İşletme İktisadl Enstitüsü Yönetim Dergisi, 25(77), 39-78. 
Omar, M., Williams, R. L. ve Lingelbach, D. (2009). Global Brand Market-Entry To Manage Corporate Reputation. Journal of Product \& Brand Management, 18 (3), 177-187.

Öğüt, A., Akgemci, T., Kocabacak, A. ve Şahin, E. (2007). İşletmelerde Düşünce Aşamasındaki Patent Aşamasına Uzanan Süreçte Yenilik Stratejileri ve Buluş Yönetimi. Selçuk Üniversitesi Sosyal Bilimler Enstitüsü Dergisi, (17), 413425.

Özbek, H. ve Atik, H. (2014). İnovasyon Göstergeleri Bakımından Türkiye'nin Avrupa Birliği Ülkeleri Arasındaki Yeri: İstatistiksel Bir Analiz. Erciyes Üniversitesi İktisadi ve İdari Bilimler Fakültesi Dergisi, 42 (Temmuz Aralık), 193-210.

Padgett, R. C. ve Leite, R. C. M. (2012). The İmpact of R\&D İntensity on Corporate Reputation: Interaction Effect of İnnovation with High Social Benefit. Intangible Capital, 8(2), 216-238.

Penrose, E. (1959). The Theory Of The Growth Of The Firm, Blackwell Publishing, Oxford.

Perrin, B. (2002). How To and How Not To Evaluate Innovation. Evaluation, $8(1), 13-28$.

Pesaran, H. M. (2015). Time Series and Panel Data Econometrics. Oxford University Press.

Peters, T. (1991). Get Innovative Or Get Dead. California Management Review, 33 (2), 9-23.

Petkova, A. P., Wadhwa, A., Yao, X. ve Jain, S. (2014). Reputation and decision making under ambiguity: A study of US venture capital firms' investments in the emerging clean energy sector. Academy of Management Journal, 57(2), 422-448.

Pfeffer, J. ve Salancik, G. R. (1978). The External Control of Organizations: A Resource Depen dence Approach, Harper and Row Publishers, New York.

Porter, E. M, (2011). Rekabet Üzerine: Bir Harvard Business Review Kitabı, P1nar Şiraz (Haz.), İstanbul, Optimist Yayınları.

Porter, E. M. (1990). The Competitive Advantage of Nations. Harvard Business Review, (March- April), 73- 93.

Rhee, M. (2009). Does Reputation Contribute to Reducing Organizational Errors? A Learning Approach. Journal of Management Studies, 46(4), 676-703

Rindova, V. P. (1997). The Image Cascade and The Formation of Corporate Reputations. Corporate Reputation Review, 1 (1-2), 188-194. 
Rindova, V. P., Williamson, I. O. ve Petkova, A. P. (2010). Reputation as an intangible asset: Reflections on theory and methods in two empirical studies of business school reputations. Journal of Management, 36(3), 610-619.

Rindova, V. P., Williamson, I. O., Petkova, A. P. ve Sever, J. M. (2005). Being Good or Being Known: An Empirical Examination of the Dimensions, Antecedents, and Consequences of Organizational Reputation. Academy of Management Journal, 48(6), 1033-1049.

Roberts, P. W. ve Dowling, G. R. (2002). Corporate Reputation and Sustained Superior Financial Performance. Strategic Management Journal, 23(12), 1077 $-1093$.

Rose, C. ve Thomsen, S. (2004). The Impact of Corporate Reputation on Performance: Some Danish Evidence. European Management Journal, 22 (2), 201-210.

Saylı, H., Veysel, A., Kızıldağ, D., ve Uğurlu, Y. (2009). Etik, Kurumsal İtibar ve Kurumsal Performans İlişkisini Belirlemeye Yönelik İlk 500 İşletme İçinde Yapılmış Bir Araştırma. Süleyman Demirel Üniversitesi iktisadi ve İdari Bilimler Fakültesi Dergisi, 14(2), 171-180.

Schwaiger, M. (2004). Components and Parameters of Corporate Reputation - An Emprical Study. Schmalenbach Business Review, 56, 46-71.

Schwalbach, J. (2000). Image, Reputation und Unternehmenswert, in: Baerns, Information und Kommunikation in Europa. Forschung und Praxis. Transnational Communication in Europe Research and Practice, Juliana Barbara/Raupp (Ed.), 287-297.

Shane, S. (1993). Cultural Influences on National Rates of Innovation. J. Bus. Ventur, 8, 59-73.

Steenvoorden, O. (2017). The Effect of Firm Reputation and CEO Celebrity on the Innovative Behavior of a Firm, Yayımlanmamış Yüksek Lisans Tezi, University of Amsterdam.

Stuart, T. E. (2000). Interorganizational Alliances and The Performance Of Firms: A Study Of Growth and Innovation Rates In A High-Technology Industry. Strategic Management Journal, 21(8), 791-811.

Teece, D. J (1986). Profiting From Technological Innovation: Implications For Integration, Collaboration, Licensing And Public Policy. Research Policy, 15(6), 285.

Türköz, T. (2020). Kurumsal Yönetim İlkelerine Uyum ile Kurumsal İtibar İlişkisinde Aile Sahipliğinin Rolü. Yayınlanmamış Doktora Tezi, Eskişehir Osmangazi Üniversitesi, Sosyal Bilimler Enstitüsü. 
Tylecote, A. (1996). Cultural Differences Affecting Technological Innovation in Western Europe. European Journal of Work \& Organizational Psychology, 5 (1), 137-174.

Vitezić, N. (2011). Corporate Reputation And Social Responsibility: An Analysis Of Large Companies In Croatia. International Journal of Economics and Business Research, 8(10), 85-96.

Walker, K. (2010). A Systematic Review Of The Corporate Reputation Literature: Definition, Measurement, and Theory. Corporate Reputation Review, 12(4), 357-387.

Weigelt, K. ve Camerer, C. (1988). Reputation And Corporate Strategy: A Review Of Recent Theory and Applications. Strategic Management Journal, 9, 443-454.

Wernerfelt, B. ve Montgomery, C. A. (1988). Tobin's Q and the Importance of Focus in Firm Performance. The American Economic Review, 1(78), 246-250.

Yavuz, Ç. (2010). İşletmelerde İnovasyon-Performans İlişkisinin İncelenmesine Dönük Bir Çalışma. Girişimcilik ve Kalkınma Dergisi, 5(2), 143-173.

Yener, M. ve Ergun, S. (2014). Ittibar Yönetimi: Tanım, Ölçüm ve Teori. Haluk Sümer ve Helmut Pernsteiner (Ed.). İtibar Yönetimi, içinde (3-23), Beta Yayınları, İstanbul.

Yeşil, S. ve Sibel P. (2017). Farklılıkların Yönetimi, Kurumsal İitibar ve İşletme Performansı Üzerine Etkileri:Tekstil Sektöründe Bir Alan Araştırması. Kahramanmaraş Sütçü İmam Üniversitesi İktisadi ve İdari Bilimler Fakültesi Dergisi, 7(2), 173-194.

Yeşil, S., Çınar, Ö. ve Uzun, E. (2010). Kahramanmaraş'ta Faaliyet Gösteren İşletmelerin Yenilik Faaliyetleri Üzerine Bir Alan Çalışması. Bilgi Ekonomisi ve Yönetim Dergisi, 5(2), 81-100.

Young, D. (1996). Building Your Company's Good Name, USA: Amacom.

Yücel, N. ve Toprak, C. (2019). Sosyal İnovasyonun Marka İmajına Olan Etkisi. I $\breve{g} d ı r$ Üniversitesi Sosyal Bilimler Dergisi, 20, 435-457. 